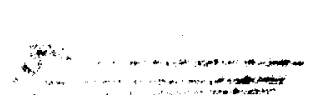

Report of Investigation

Utah Geological and Mineral Survey

No. 141

GEOTHERMAL NVESTIGATIONS AT SELECTED

THERMAL SYSTEMS OF THE NORTHERN WASATCH FRONT

WEBER AND BOX ELDER COUNTIES, UTAH

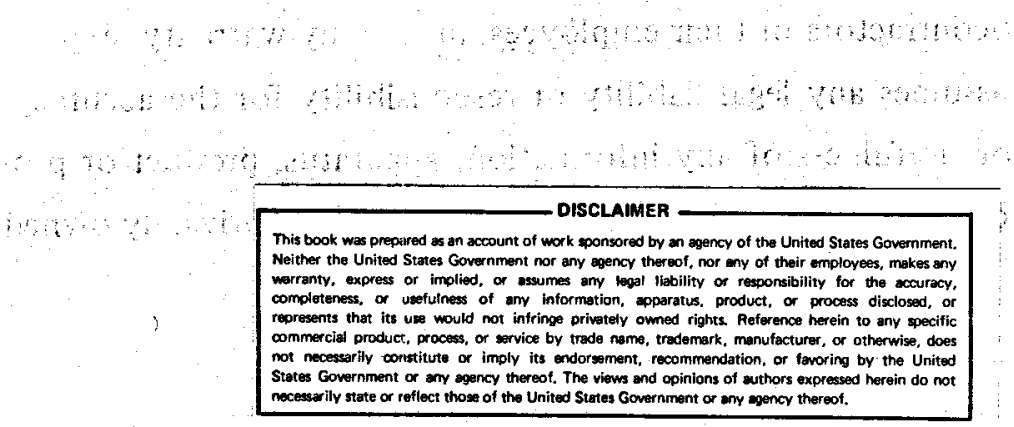

by

Peter Murphy, Geologist

J. Wallace Gwynn, Research Geologist

Research Geology Section

November, 1979

Prepared for

Department of Energy/Division of Geothermal Energy

Under Contract DE-AS07-77ET28393

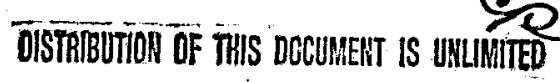




\section{DISCLAIMER}

This report was prepared as an account of work sponsored by an agency of the United States Government. Neither the United States Government nor any agency Thereof, nor any of their employees, makes any warranty, express or implied, or assumes any legal liability or responsibility for the accuracy, completeness, or usefulness of any information, apparatus, product, or process disclosed, or represents that its use would not infringe privately owned rights. Reference herein to any specific commercial product, process, or service by trade name, trademark, manufacturer, or otherwise does not necessarily constitute or imply its endorsement, recommendation, or favoring by the United States Government or any agency thereof. The views and opinions of authors expressed herein do not necessarily state or reflect those of the United States Government or any agency thereof. 


\section{DISCLAIMER}

Portions of this document may be illegible in electronic image products. Images are produced from the best available original document. 


\section{NOTICE}

This report was prepared to document work sponsored by the United States Government. Neither the United States nor its agent, the United States Department of Energy, nor any Federal employees, nor any of their contractors, subcontractors or their employees, makes any warranty, express or implied, or assumes any legal liability or responsibility for the accuracy, completeness, or usefulness of any information, apparatus, product or process disclosed, or represents that its use would not infringe privately owned rights:

\section{NOTICE}

Reference to a company or product name does not imply approval or recommendation of the product by the Utah Geological and Mineral Survey or the U.S. Department of Energy to the exclusion of others that may be suitable. 


\section{TABLE OF CONTENTS}

Page

Abstract $\ldots \ldots \ldots \ldots \ldots \ldots \ldots \ldots \ldots \ldots \ldots \ldots \ldots \ldots \ldots \ldots \ldots \ldots \ldots \ldots \ldots$

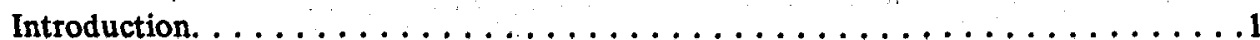

Regional Structural Setting $\ldots \ldots \ldots \ldots \ldots \ldots \ldots \ldots \ldots \ldots \ldots \ldots \ldots \ldots \ldots \ldots \ldots$

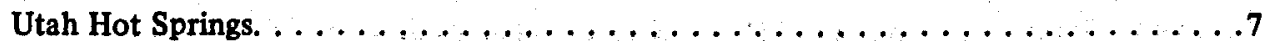

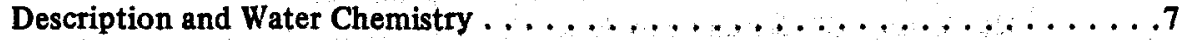

Pleasant View Salient - Geology and structure. . . . . . . . . . . . 10

Subsurface Data . . . . . . . . . . . . ..............13

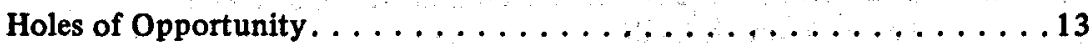

Gradient Hole UT/GH-B. . . . . . . . . . . . . . . 13

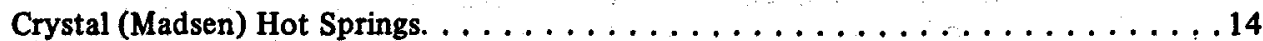

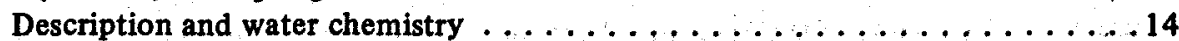

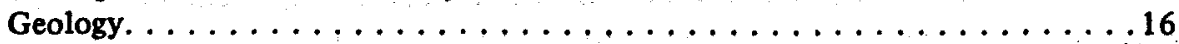

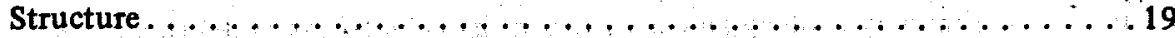

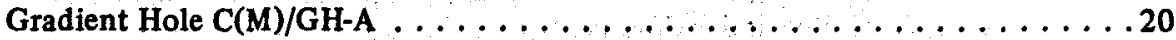

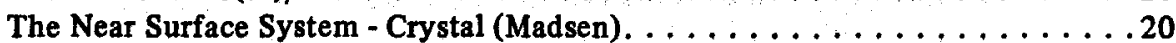

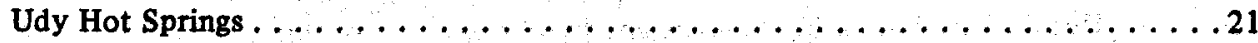

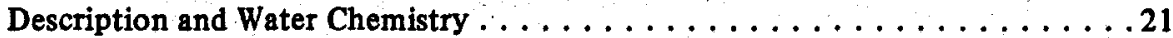

Geologic and Structural Setting $\ldots \ldots \ldots \ldots \ldots \ldots \ldots \ldots \ldots \ldots \ldots \ldots \ldots \ldots \ldots$

The West Hills. . . . . . . . . . . . . . . . . . . . . . 24

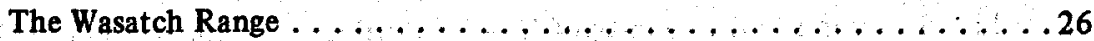

The Malad River Valley Graben System . . . . . . . . . . . . . . . . . 27

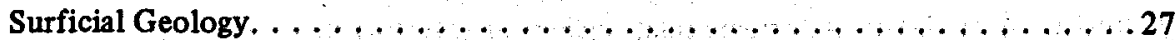

Shallow Ground Temperature Survey $\ldots \ldots \ldots \ldots \ldots \ldots \ldots \ldots \ldots \ldots \ldots \ldots \ldots$

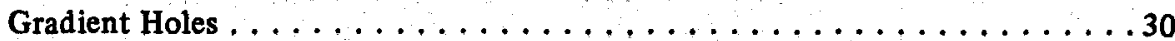

The near-surface hydrogeologic system $\ldots \ldots \ldots \ldots \ldots \ldots \ldots \ldots \ldots \ldots$

Little Mountain-south geothermal area $\ldots \ldots \ldots \ldots \ldots \ldots \ldots \ldots \ldots$

Description $\ldots \ldots \ldots, \ldots, \ldots \ldots \ldots \ldots \ldots \ldots \ldots \ldots \ldots \ldots \ldots \ldots \ldots \ldots \ldots$

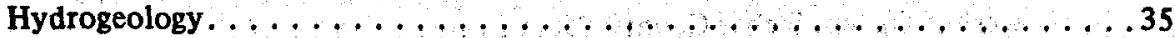

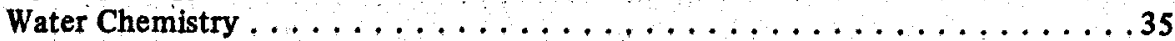

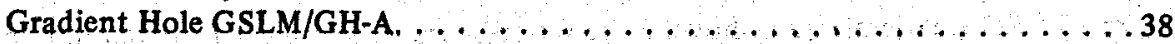

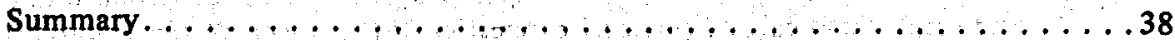

Heat Source for Northern Wasatch Front Geothermal Systems . . . . . . . . . 38

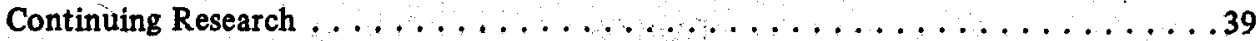

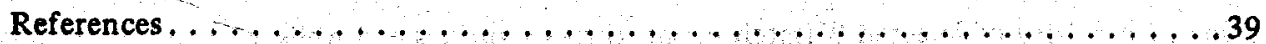

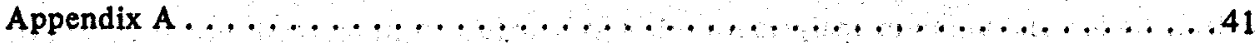

Well and Spring numbering system $\ldots \ldots \ldots \ldots \ldots \ldots \ldots \ldots \ldots \ldots \ldots \ldots \ldots \ldots \ldots \ldots \ldots$

Temperature Gradient Hole Logs $\ldots \ldots \ldots \ldots \ldots \ldots \ldots \ldots \ldots \ldots$. . . . . . . . . . . . . . 


\section{LIST OF ILLUSTRATIONS}

Figure 1. Index map showing major physiographic provinces of Utah $\ldots \ldots \ldots \ldots$

Figure 2. Index map of northern Wasatch Front indicating locations of springs in this report $\ldots \ldots \ldots \ldots \ldots \ldots \ldots \ldots \ldots$

Figure 3a. Regional gravity of the Wasatch Front, Layton, Utah to Woodruff, Idaho .......................

Figure 3b. Regional gravity of the Wasatch Front, Layton, Utah to

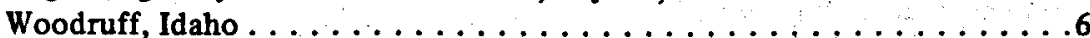

Figure 4. Spring locations, and shallow ground temperatures at Utah Hot Springs, Weber and Box Elder Counties, Utah . . . . . . . . . . . . .9

Figure 5. Lineaments of the Pleasant View Salient, Box Elder and

Weber Counties, Utah. . . . . . . . . . . . . . . . . . . . . 12

Figure 6. Northern Utah Hot Springs Temperature Gradients . . . . . . . . . . 15

Figure 7. Lineaments of the Madsen Salient, Box Elder County, Utah . . . . . . 17

Figure 8. Preliminary geology and structure in the vicinity of Crystal (Madsen)

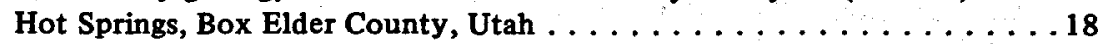

Figure 9. Generalized cross-section of the area south of Crystal (Madsen) Hot Springs illustrating geologic and hydrologic relationships. . . . . . . 22

Figure 10. Surface features at Udy Hot Springs, Box Elder County, Utah . . . . . . 23

Figure 11. Structures in the vicinity of Udy Hot Springs, Box Elder County, Utah . . 25

Figure 12. A model of hydrologic relationships at Udy Hot Springs, Box Elder County, Utah . . . . . . . . . . . . . . . 32

Figure 13. Water temperatures of springs and flowing wells in the vicinity of Little-Mountain-South, Weber County, Utah. . . . . . . . . . . . . . . . 34

Figure 14. Locations of warm water wells and GSLM/GH-A at Little Mountain west of Ogden, Weber County, Utah . . . . . . . . . . . . . 36

Figure 15. Schematic diagram showing the water-bearing zones near Little Mountain and some chemical and physical properties of the water. Water analyses for wells 14 and 15 in table 1. Modified from Bolke and Waddell, 1972 ..37

\section{TABLES}

Table 1. Chemistry of selected Wasatch Front thermal springs and wells $\ldots \ldots \ldots \ldots$

Table 2. Radon and uranium analyses for selected Wasatch Front thermal springs . . 11

Table 3. Approximate total dissolved solids and maximum reported temperatures at selected Wasatch Front thermal springs. . . . . . . . . . . . 11

Table 4. Temperature and conductivity measurements, at the Morning Glory hole and UDY/GH-A Udy Hot Springs, Box Elder County, Utah. . . . . . . . . . . 29

Table 5. Water chemistry from UDY/GH-A and UDY/GH-B, and the Morning Glory Hole at Udy Hot Springs in Box Elder County, Utah.. . . . . . 29 


\title{
GEOTHERMAL INVESTIGATIONS AT SELECTED THERMAL SYSTEMS OF THE NORTHERN WASATCH FRONT WEBER AND BOX ELDER COUNTIES, UTAH
}

\author{
by \\ Peter Murphy, Geologist \\ J. Wallace Gwynn, Research Geologist \\ Research Geology Section \\ November, ' 1979
}

\section{ABSTRACT}

Numerous thermal springs are present along the Wasatch Front from Utah valley on the south to the state line on the north. These systems are just west of the Wasatch Mountains at the eastern edge of the Basin and Range physiographic province and within the active seismic zone referred to as the Intermountain Seismic Belt. This Report of Investigation is a summary of UGMS investigations at four northern wasatch front geothermal systems: Utah, Crystal (Madsen), and Udy hot springs; and the Little Mountain - south system. All of these resources are deep circulation systems and the water is heated by the normal heat flow of the Basin and Range Province. Heat from volcanic sources is not believed to contribute to the warming of any northern wasatch front springs. Data collected under the DOE/DGE state coupled program is presented for use by individuals interested in these systems.

\section{INTRODUCTION}

Under contract with the U. S. Department of Energy/Division of Geothermal Energy (DOE/DGE), the Utah Geological and Mineral Survey (UGMS) has been conducting research to advance the utilization of low temperature geothermal heat in the state of Utah. Activities related to the contract (originally EG-77-S-07-1679 but later changed to DE-AS07-77ET28393) began on July 1, 1977 and will continue into 1980 .

To date, UGMS has concentrated its investigations along the wasatch front from Utah Valley on the south to the Utah-Idaho state line on the north (figures 1 and 2). The reasons for the concentration of effort in this area of the state are as follows: 1) the concentration of an apparent geothermal resources in this area and 2) the three major population centers of the state: (north to south) Ogden, Salt Lake City, and Provo lie within the region. The co-location of low temperature geothermal resources and potential users increases the possibility of timely resource development. Therefore, resource information in populated areas should encourage the development of low temperature resources for direct heat applications by providing a data base from which potential users can make informed decisions. At the same time, investigations of the Basin and Range Province geothermal 


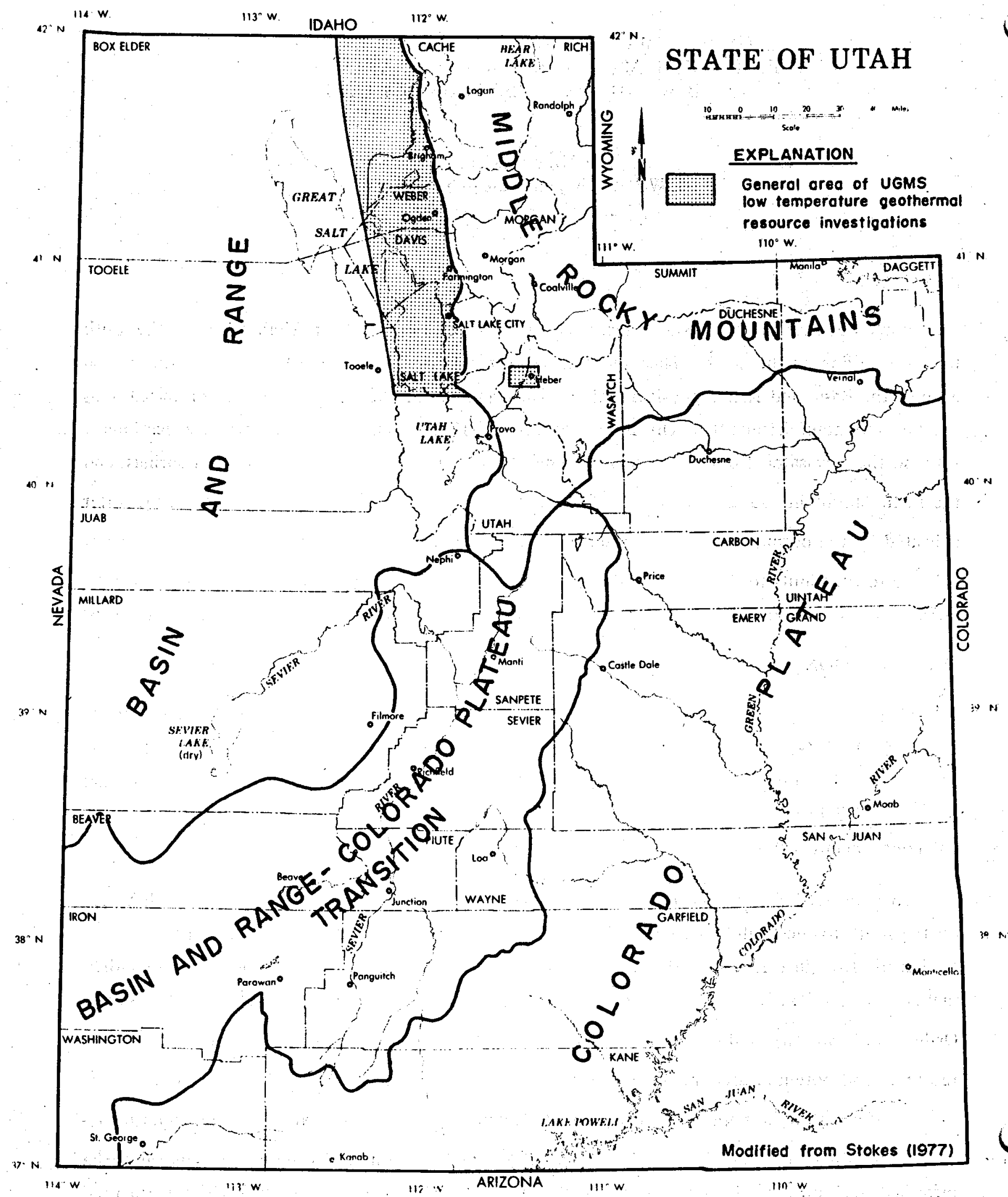

Index map showing major physiographic provinces of Utah

Flgure I 


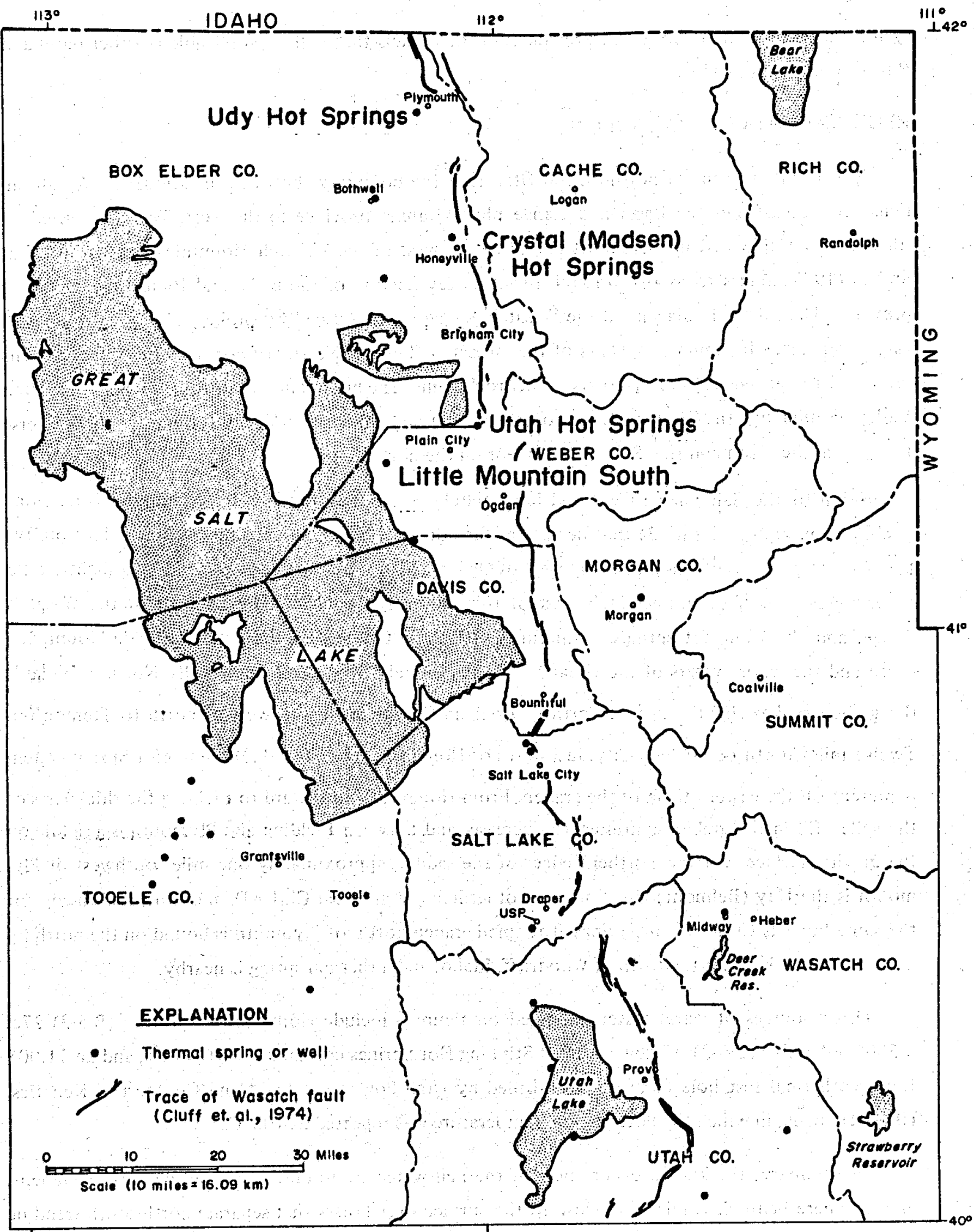


systems of the Wasatch Front will provide data for models that will be applicable to other Basin and Range geothermal systems.

\section{REGIONAL STRUCTURAL SETTING}

The Wasatch Front of north-central Utah is at the boundary between the Middle Rocky Mountains on the east and the Basin and Range physiographic province to the west. The geothermal resources to be discussed in this report are all to the west of the Wasatch Mountains and within what Stokes (1977) refers to as the Wasatch Front Valley Section of the Basin and Range physiographic province. The lowland adjacent to the Wasatch Range and described by Stokes (1977) as a series of valleys separated by spurs or salients of the Wasatch Range is a series of northward trending grabens separated to varying degrees by horsts, or bedrock highs. The best examples of these grabens are: Utah Valley (bound by the Traverse Range on the north) and the Jordan Valley (bound by the Traverse Ranges on the south and the Salt Lake Salient on the north).

North of the Salt Lake Salient and immediately adjacent to the Wasatch Mountains is an elongate complex graben (figure 3 ) that persists as far north as the town of fielding in Box Elder County. The deepest portions of this graben are west of Ogden and Willard, and are separated by a slight saddle on the gravity surface. Immediately east of this saddle is the Pleasantview salient of the Wasatch Range, and the Utah hot springs geothermal system. To the west of the saddle is Little Mountain south and the warm waters of the Great Salt Lake Mineral Corporation water wells. North of Willard, the graben strikes slightly east of north to Brigham City then slightly west of north to Tremonton. Twelve miles north of Brigham City, just north of Honeyville, the Crystal (Madsen) Hot Spring system is present on the eastern flank of the graben. From Honeyville northward to Fielding the thicknesss of the valley fill in the graben continues to decrease, and between Fielding and Plymouth is a saddle on the gravity surface. On the northern edge of the saddle, approximately one mile southwest of Plymouth is the Udy (Belmont) Hot Springs geothermal system. Near Cutler Dam on the eastern edge of the same horst is Cutler Warm Springs. The small graben north of Plymouth is bound on the north by a horst located beneath the town of Woodruff, Idaho, and a thermal spring is nearby.

Other sources of warm water indicated on figure 3 include Hopper Hot Springs, (B-5-3) 27c; a 500 foot well, (B-9-3) $37 \mathrm{cba}$, south of Stinking Hot Springs containing $74^{\circ} \mathrm{C}$ water; and an 11,005 foot geothermal test hole (Davis No. 1) drilled by Utah Power and Light and Geothermal Kenetics, (B-10-2) $16 \mathrm{cba}$, in which the bottom hole temperature was rèported as $105^{\circ} \mathrm{C}$.

In summary, the known occurrences of thermal water are found: 1) at the margins of grabens,

and 2) where bedrock is relatively close to the surface over horsts that separate north-south trending grabens. To date, thermal waters have not been encountered in the deep portions of the grabens. 


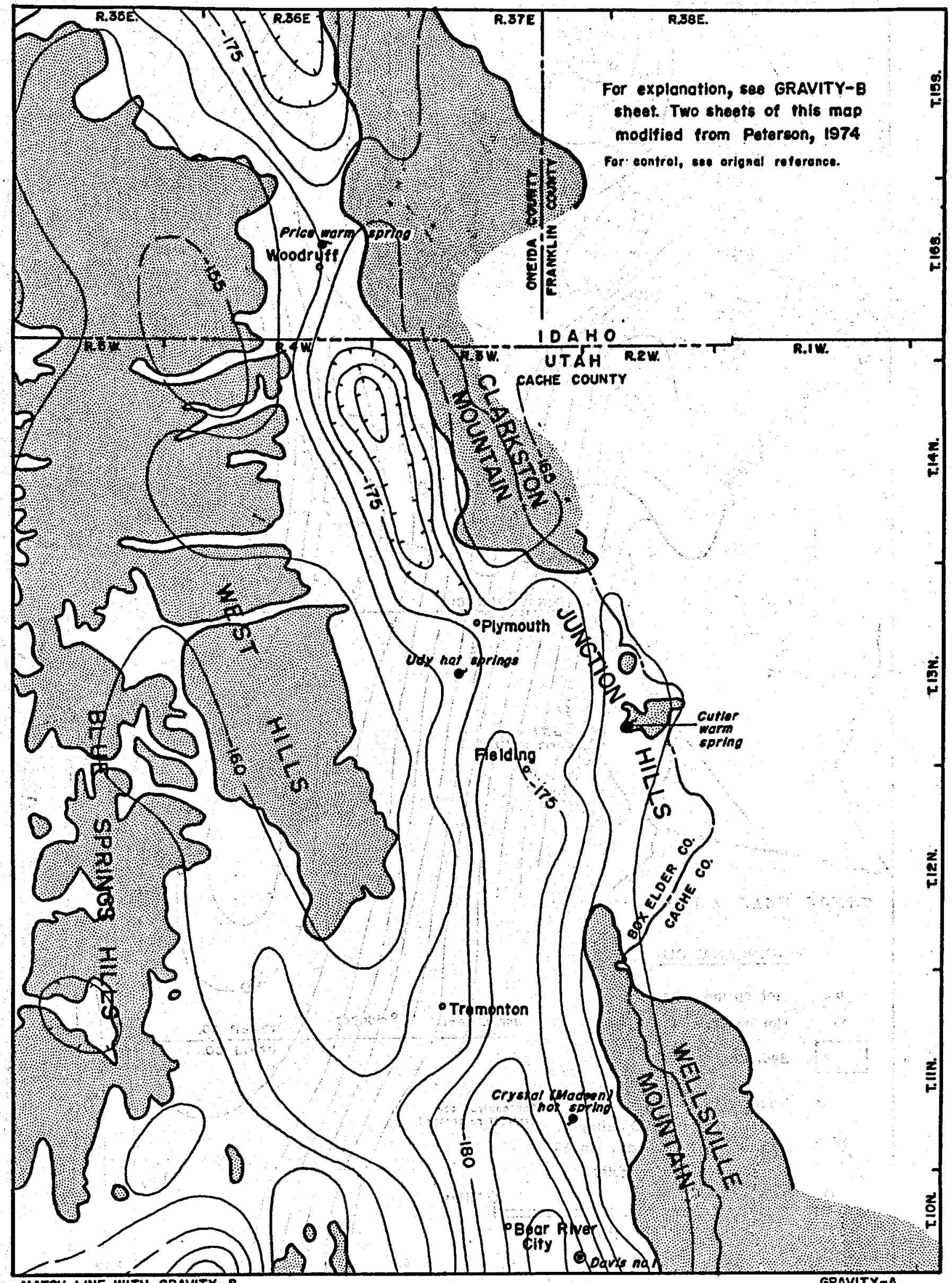

Regional gravity of the Wasatch Front, Layton, Utah to Woodruff, Idaho 


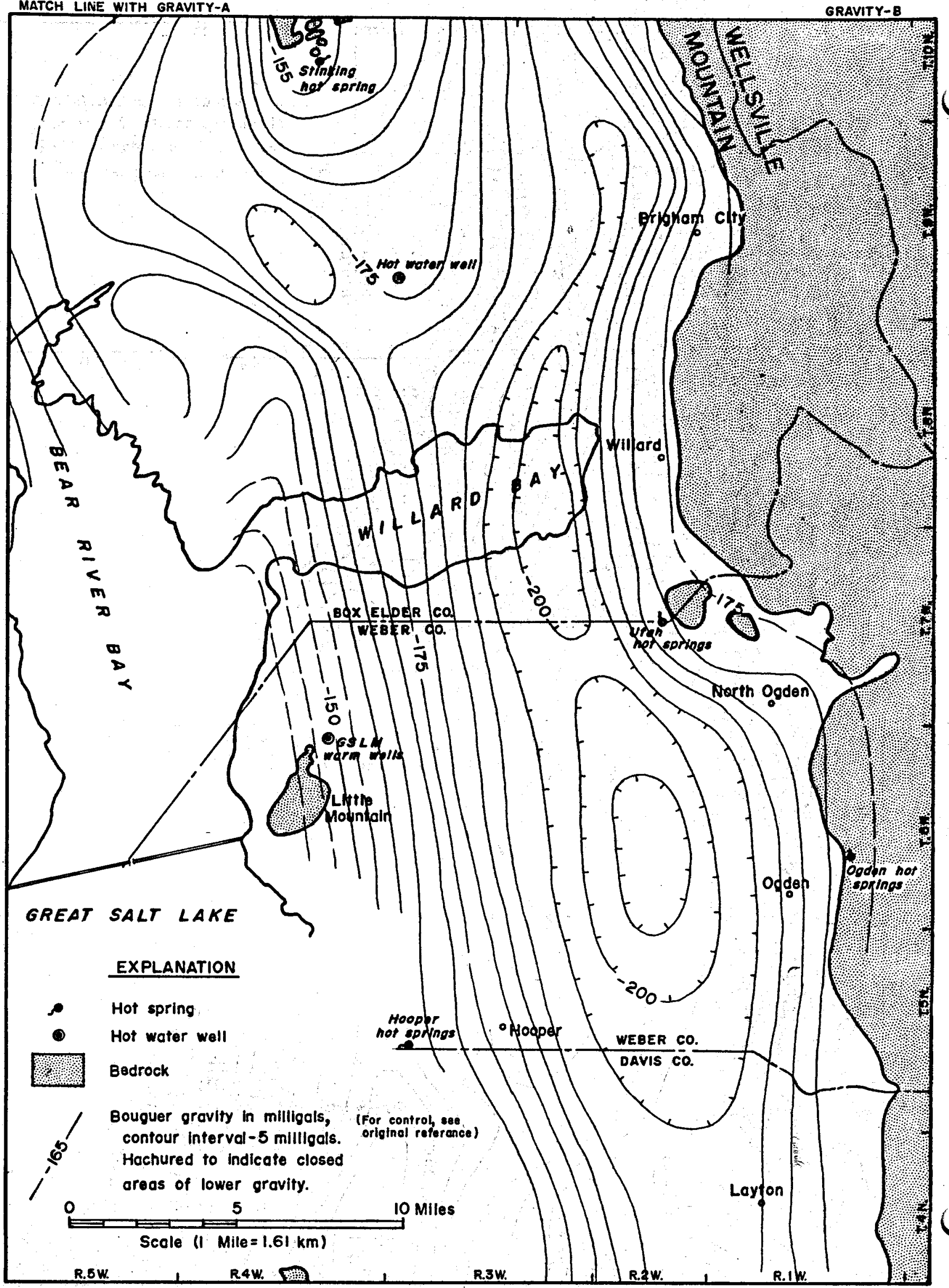

Regional gravity of the Wasatch Front, Layton, Utah to Woodruff, Idaho 
UTAH HOT SPRINGS

Description and Water Chemistry

Utah Hot Springs, (B-7-2) 14 dca, issues from valley fill at the western edge of the Pleasant View salient approximately $90 \mathrm{~m}$ (300 feet) west of Utah Route 89 on the Box Elder-Weber County line (figure 4). From the springs, Willard is $8 \mathrm{~km}$ (5 miles) to the north and North Ogden is $6.4 \mathrm{~km}$ (4 miles) to the southeast. The area surrounding the springs is a corridor for vehicular and rail traffic as well as for electrical transmission lines and gas pipelines. The springs are controlled and the discharge collected so that both the land and water can be used. The main spring orifaces are confined in pools by stone walls that are only a few tens of feet from the Union Pacific railroad tracks. The spring discharge is channeled north and westward to a resort that is presently abandoned. A greenhouse complex operated by Allen Plant Company uses a small portion of the spring discharge for heating during the winter months. All the water from the main springs eventually drains to the swampy area north of the abandoned resort. The maximum temperature measured at the springs by UGMS employees has been $63^{\circ} \mathrm{C}$, although the maximum reported temperature of the spring discharge is only $58.5^{\circ} \mathrm{C}$ (table 1).

A spring oriface not discussed by either Milligan, et. al. (1966) or Mundorf (1970) is located approximately $152 \mathrm{~m}$ (500 feet) southeast of the main springs described above (figure 4). The water was previously used in an abandoned swimming pool just east of the Union Pacific tracks. The temperature of the spring discharge was measured at $40^{\circ} \mathrm{C}$ where the flow passes under the tracks.

The springs described above are not the only springs present in the area. The zone between the U.P. tracks on the west and the quartzite outcroppings to the east contains a number of springs for approximately one mile to the north (figure 4). The area immediately north of the springs is swampy and contains numerous seeps. A concrete box under one of the old county roads contains $25^{\circ} \mathrm{C}$ water. Just north and east of the abandoned resort a spring of $20^{\circ} \mathrm{C}$ water flows from a spring house. A seep of $34^{\circ} \mathrm{C}$ water flows from a crack in the concrete floor of the Allen Plant Company greenhouse.

A limited shallow ground temperature survey was conducted at Utah Hot Springs in mid-August 1978. The locations of the 1.0-1.5 meter deep holes and contours of equal temperatures are present in figure 4. The major anomally is centered around the main spring orifaces. To the north temperatures descrease rapidly with distance from the springs. To the south the decrease is not as rapid. Although control is somewhat limited, the $25^{\circ} \mathrm{C}$ isotherm extends as far west as the Allen Plant Company greenhouse and may reflect the subsurface drainage of thermal waters away from the spring in the permeable material encountered during gradient hole drilling. 
Table 1. Chemistry of selected Wasatch Front thermal springs and wells

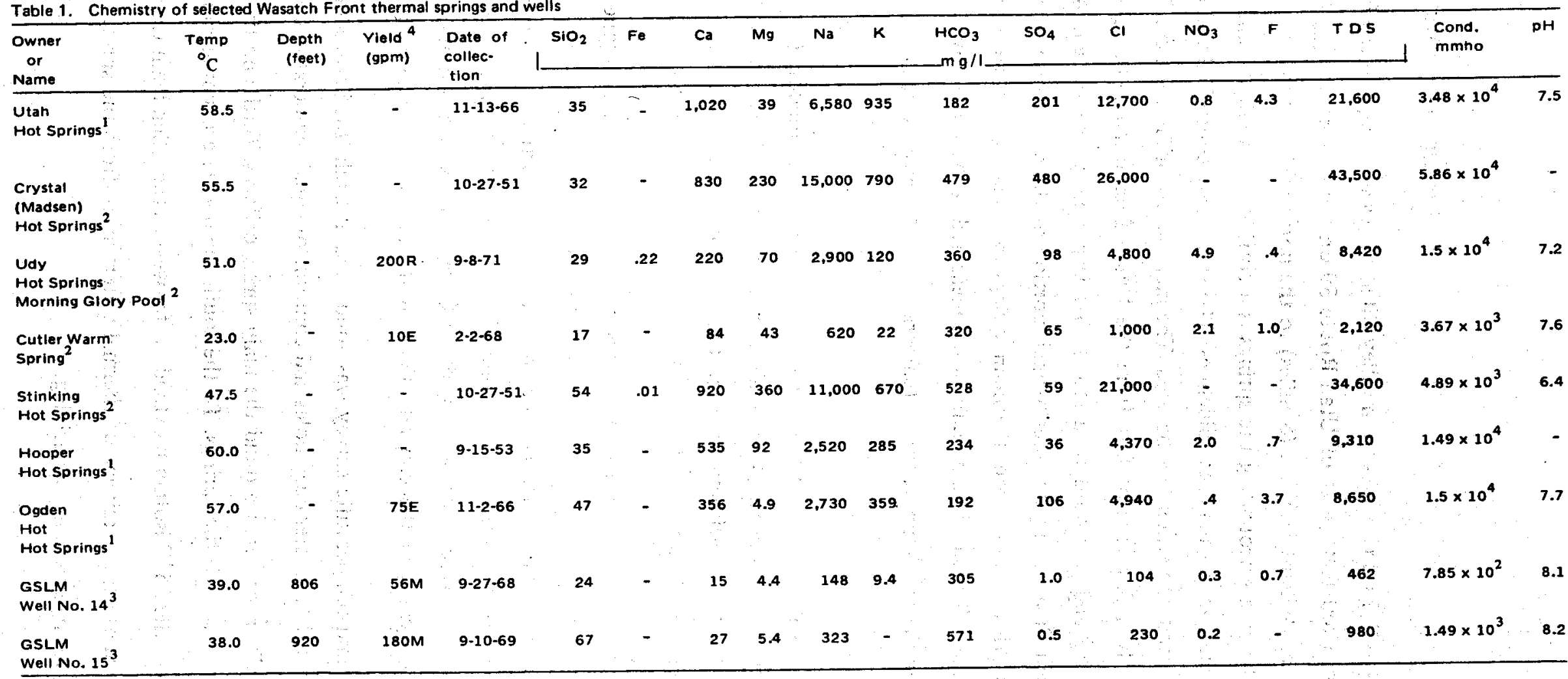

Well No. $15^{3}$

Mundorkf, 1970 and and McGreevy, 1973

${ }^{3}$ Botke and Waddell, 1972

${ }^{4} R$ - reported

E - estimated

M-measured 
$\cdot 9 \cdot$

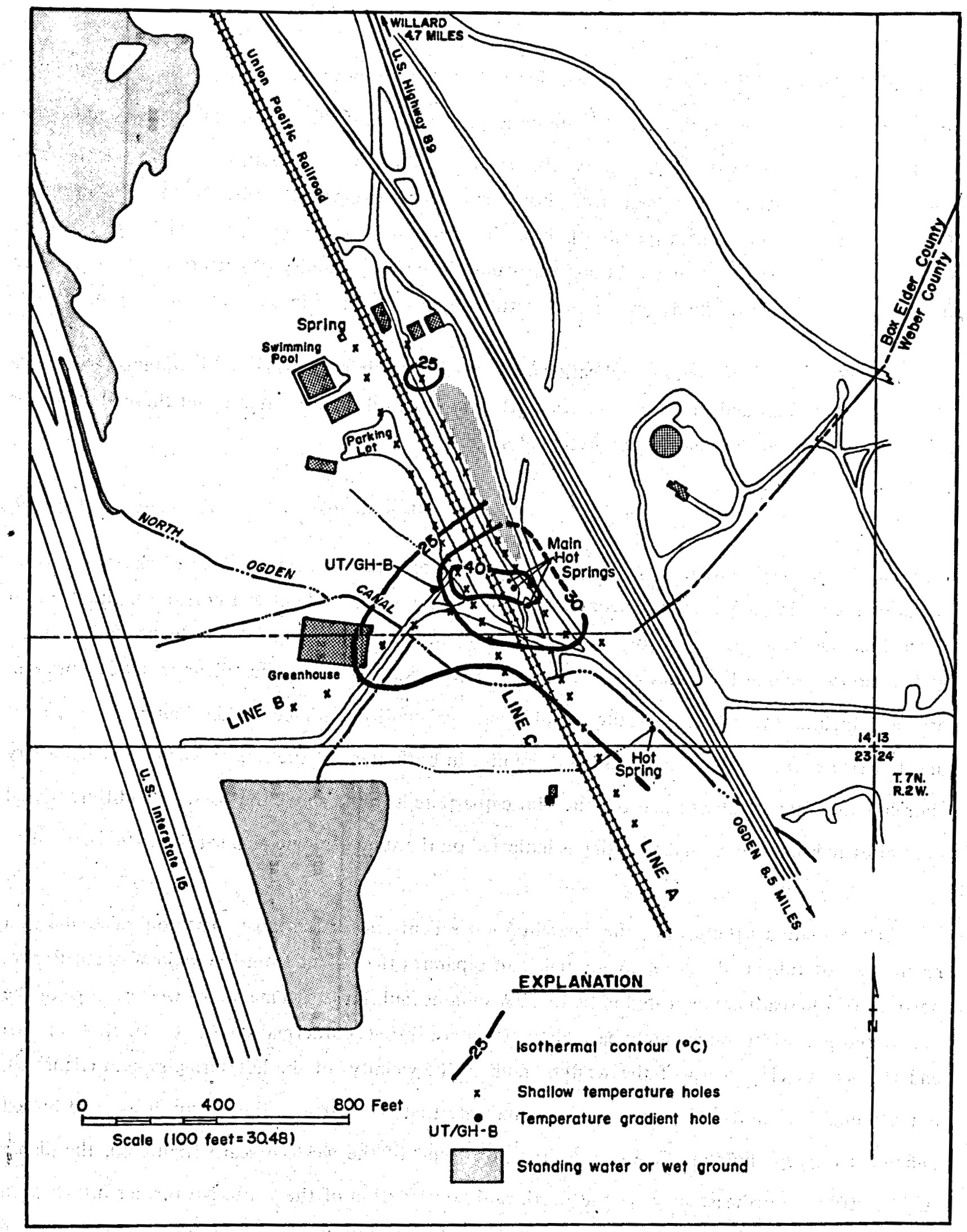

Spring locations, and shallow ground temperatures at Utah Hot Springs, Weber and Box Elder Counties, Utah 
The quality of the water at Utah Hot Springs is relatively poor. A total dissolved solids content of over $21,000 \mathrm{mg} / 1$ makes the water saline in nature, and almost $90 \%$ of the TDS is $\mathrm{Na}$ and $\mathrm{Cl}$ ions (table 1). In addition to the high salinity, the water contains 3 to $5 \mathrm{mg} / 1$ dissolved iron that oxidizes when the water is aerated. The precipitated iron has caused problems with using the water as a primary fluid for space heating, and disposable polyurethane tubing is presently being used for pipes in the greenhouse. With both hot and cold springs issuing in close proximity of each other, there is little doubt that the thermal fluids are mixing with nonthermal water in some unknown proportions.

In addition to major anions and cations, the water at Utah Hot Springs also contains measurable quantities of radium and uranium. Values of $\mathrm{Ra}$ and $\mathrm{U}$ for selected Wasatch Front thermal springs as reported by Felmlee and Cadigan are presented in table 2.

Pleasant View Salient - Geology and structure

The Wasatch Mountains east of the Ogden area are a complex series of thrust sheets involving rocks of Precambrian and early Paleozoic age. The Pleasant View salient is a portion of the Wasatch range that has been displaced downward relative to the range, but has remained high relative to the graben floors beneath the valley fill to the west. The rocks exposed on the salient are all Cambrian in age, and include the Tintic quartzite, Ophir shale, and undifferentiated middle Cambrian dolomites and limestones that are chiefly Maxfield dolomite. In both areas of the salient where the Quaternary shoreline deposits are absent or thin, the Tintic quartzite is found above the younger undifferentiated dolomites and limestones, and thrusting is indicated on the state geologic map (Stokes, 1963).

The bounding structures of the Pleasant View salient are for the most part concealed and as a result are not fully understood. A normal fault separates the salient from the main Wasatch Range; portions of the scarp are indicated in figure 5. A sinuous fault line scarp marks the western edge of the salient and is present immediately east of the Utah hot spring geothermal system. Cluff, et. al. (1970) end the second class scarp of the western fault in the vicinity of the hot spring system (figure 5), but a number of third class lineations may indicate that the scarp continues southeastward buried under Quaternary shoreline deposits. At the north end of the western scarp (figure 5), the planar surface striking northeast may be the northward continuation of the scarp. No further information on the locations of boundary faults is presently available, however, a detail gravity survey and an aeromagnetic survey planned for the 1979 field season will aid in accurately locating the major bounding structures buried beneath the valley fill. 
Table 2. Radon and Uranium analyses for selected Wasatch Front thermal springs. Data from Felmlee and Cadigan (1978)

\begin{tabular}{lcc}
\hline \multicolumn{1}{c}{ Spring } & $\mathrm{Ra}$ \\
$(\mu \mu \mathrm{g} / \mathrm{l})$ & $\begin{array}{c}\mathrm{U} \\
(\mu \mathrm{g} / \mathrm{l})\end{array}$ \\
\hline Wasatch Hot Spring & 27 & - \\
Becks Hot Spring & 23 & - \\
Utah Hot Spring & 66 & 0.04 \\
Crystal (Madsen) Hot Spring & 220 & 1.5 \\
Udy Hot Spring & 32 & 0.8 \\
\hline
\end{tabular}

Table 3. Approximate total dissolved solids and maximum reported temperatures at selected Wasatch Front thermal springs.

\begin{tabular}{lcc}
\hline \multicolumn{1}{c}{ Spring } & Approximate TDS (mg/1)* & Maximum reported Temperature \\
\hline Crystal & 1,500 & $86^{\circ} \mathrm{C}\left(187^{\circ} \mathrm{F}\right)$ \\
Saratoga & 1,500 & $44^{\circ} \mathrm{C}\left(111^{\circ} \mathrm{F}\right)$ \\
Udy & 7,900 & $54^{\circ} \mathrm{C}\left(121^{\circ} \mathrm{F}\right)$ \\
Wasatch & 8,600 & $42^{\circ} \mathrm{C}\left(108^{\circ} \mathrm{F}\right)$ \\
Beck & 13,700 & $55^{\circ} \mathrm{C}\left(132^{\circ} \mathrm{F}\right)$ \\
Utah & 29,200 & $62^{\circ} \mathrm{C}\left(144^{\circ} \mathrm{F}\right)$ \\
Crystal (Madsen) & 42,900 & $57^{\circ} \mathrm{C}\left(135^{\circ} \mathrm{F}\right)$ \\
From Mundorff (1970) & & \\
\hline
\end{tabular}




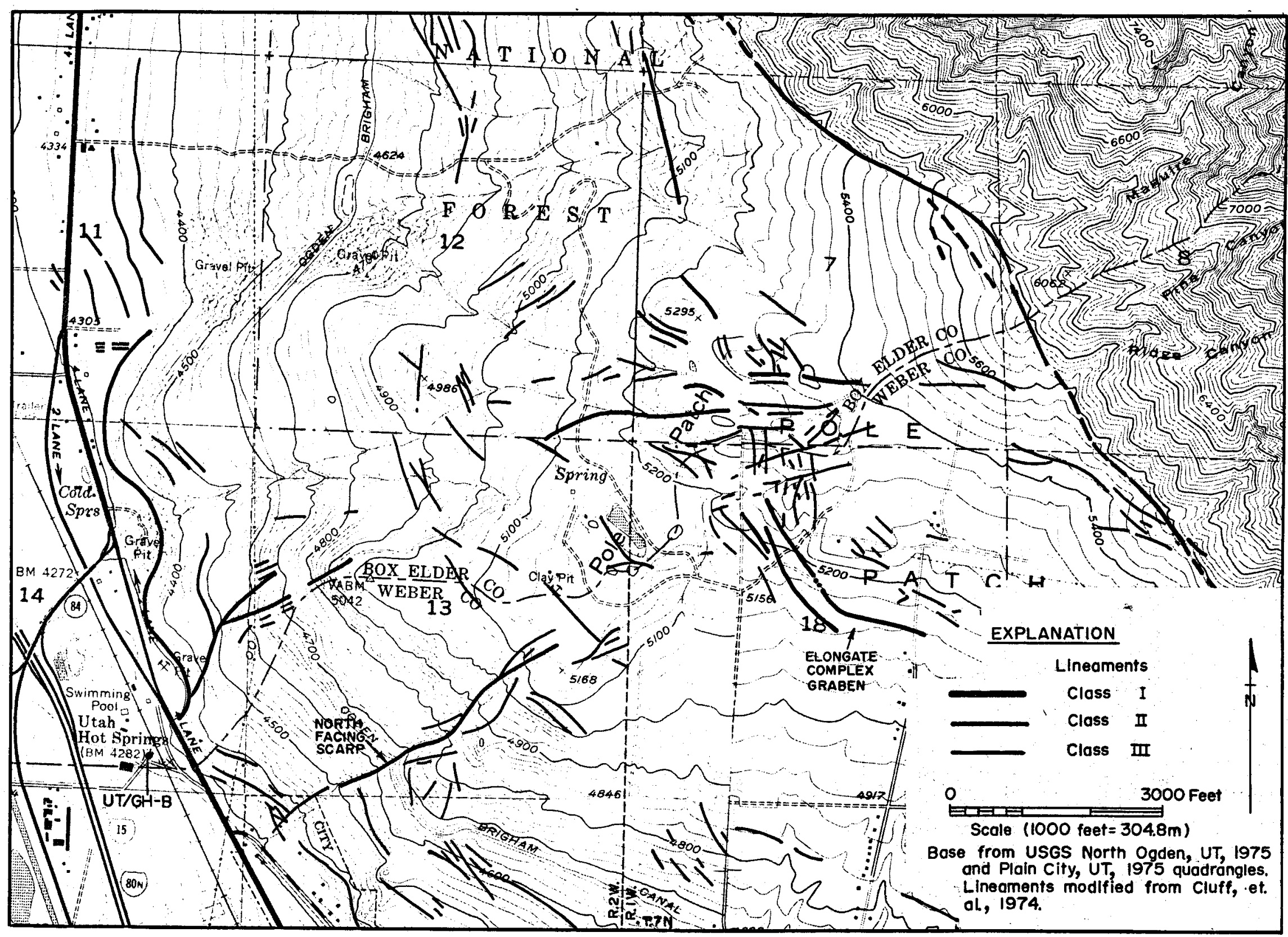

Lineaments of the Pleasant View Salient, Box Elder and Weber Counties, Utah
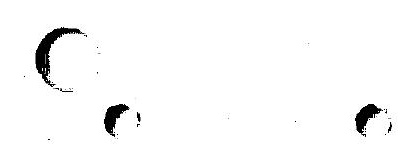
Although the lineaments internal to the Pleasant View salient appear complex, two sets of roughly perpendicular lineaments can be identified. One set of lineaments strikes northwestward, parallel to the Wasatch Range, while the other set strikes to the northeast. Both lineament sets contain Class II and Class III lineaments. Near the western edge of the salient at least two of the northeast striking lineaments intersect the fault scarp that defines the western edge of the salient; the northermost intersection is in close proximity to the thermal springs. One of the most prominent northwest striking lineaments on the salient is the elongate complex graben in T 7 N., R 1 W., Section 18.

Based on the limited geologic information presently available, the displacement on most of the internal structures does not appear to be large. The complex structures in the vicinity of the pole patch may be fractures that developed as the salient was faulted downward, or the original structures may pre-date Basin and Range faulting. The Class II lineaments that intersect the structure bounding the western end of the salient may extend northeastward across the entire salient but the actual vertical displacement across these faults is not large.

Subsurface Data

\section{Holes of Opportunity}

Very few holes have been drilled in the vicinity of Utah Hot Springs. A number of shallow water wells have been drilled about one mile to the north and south, and a uranium exploration hole was drilled in the vicinity of the springs. The site of the exploration hole has not been found but reports by residents of the area indicate the hole was very close to the springs. The hole was only drilled to a depth of approximately $30 \mathrm{~m}$ (100 feet), and probably encountered the same problems encountered by UGMS in UT/GH-B.

\section{Gradient Hole UT/GH-B}

Only one of three thermal gradient holes planned for Utah Hot Springs was actually drilled; and this hole, referred to as UT/GH-B, was only advanced to $30.5 \mathrm{~m}$ (100 feet). The material in the hole would not stay open without casing, which was driven as drilling proceeded. At a depth of $22 \mathrm{~m}$ (72 feet) a small volume of artesian flow was noted, but additional casing could still be welded to that already in the ground. In the 27 to $30 \mathrm{~m}$ (90 to $100 \mathrm{feet}$ ) interval artesian flow increased to $60 \mathrm{gpm}$ and precluded the welding of additional casing. The flow from the hole was controlled by grouting.

As indicated in the lithology $\log$ for UT/GH-B (Appendix A), the hole encountered a series of sandy clays, and sand and gravels. The overlying sandy clay confines the water in the sand and gravel and creates the artesian conditions encountered in UT/GH-B. An unquantified volume of thermal 
water is being transported away from the springs in the sand and gravel aquifer. The water flowing from UT/GH-B was $59^{\circ} \mathrm{C}$ and had a conductivity of $4.05 \times 10^{4} \mu \mathrm{mohs} / \mathrm{cm}$ at $25^{\circ} \mathrm{C}$.

At a depth of approximately $21 \mathrm{~m}$ (70 feet) pieces of saturated wood were blown from the hole. Samples of the wood (Lab. No. W-4375) were sent to the USGS Radio Carbon Lab in Reston, Virginia for carbon 14 dating and a date of $27,100 \pm 600$ years B.P. has been obtained.

As might be expected, gradient in UT/GH-B (figure 6) is a simple curve of increasing temperature. The maximum temperature approximates the temperature of the fluid in the aquifer. The hole yielded no information on thermal conditions below a depth of 100 feet.

\section{CRYSTAL (MADSEN) HOT SPRINGS}

Description and water chemistry

Crystal (Madsen) Hot Springs, (B-11-2)29da, is $2 \mathrm{~km}$ (1.3 miles) north of Honeyville immediately west of State Route 69 . The springs issue from the base of a small salient (figure 7) that at first glance resembles a very large alluvial fan developed by erosion of material from Wellsville Mountain to the east. Although there are a number of warm springs and seeps in the area, the original main spring orifice is no longer visible. Over 50 years ago the main orifice was boxed and covered. The hot $\left(54^{\circ} \mathrm{C}\right)$ and very saline $(>45,000 \mathrm{mg} / \mathrm{l}$, TDS) water of the thermal spring now discharge near the northwestern corner and along the western edge of the pool. A relatively cool, fresh spring $\left(20^{\circ} \mathrm{C}\right)$ also issues from alluvial fill only 20 feet north of the hot spring. The resort operators mix the cool and warm waters to produce the desired water temperature, then pump this mixture into the swimming pool. Two thousand feet south of the main spring a series of warm springs and seeps are present in a small branch of Salt Creek, (C-11-2) 32ab. The flow from the seeps is small, and during the winter of 1978-79 the water in this depression was frozen over.

The total flow from all of the springs and seeps at Crystal Hot Springs drains southwest via Salt Creek and was estimated by Milligan, et. al. (1966) to be approximately $9.0 \mathrm{feet}^{3} /$ second. Mundorff (1970) indicates an estimated discharge of $3.75 \mathrm{feet}^{3} /$ second for the hot spring alone. Salt Creek is a tributary of the Bear River.

The total dissolved solids content of the thermal waters at Crystal (Madsen) Hot Springs is the highest of any spring in Utah. For comparison, Wasatch Front thermal springs and their respective TDS values are listed in table 3. Over $90 \%$ of the total dissolved solids are $\mathrm{Na}$ and $\mathrm{Cl}$ ions table 1 ). Milligan, et. al. (1966) estimated that the Crystal Spring system produces 450 tons of salt per day. 


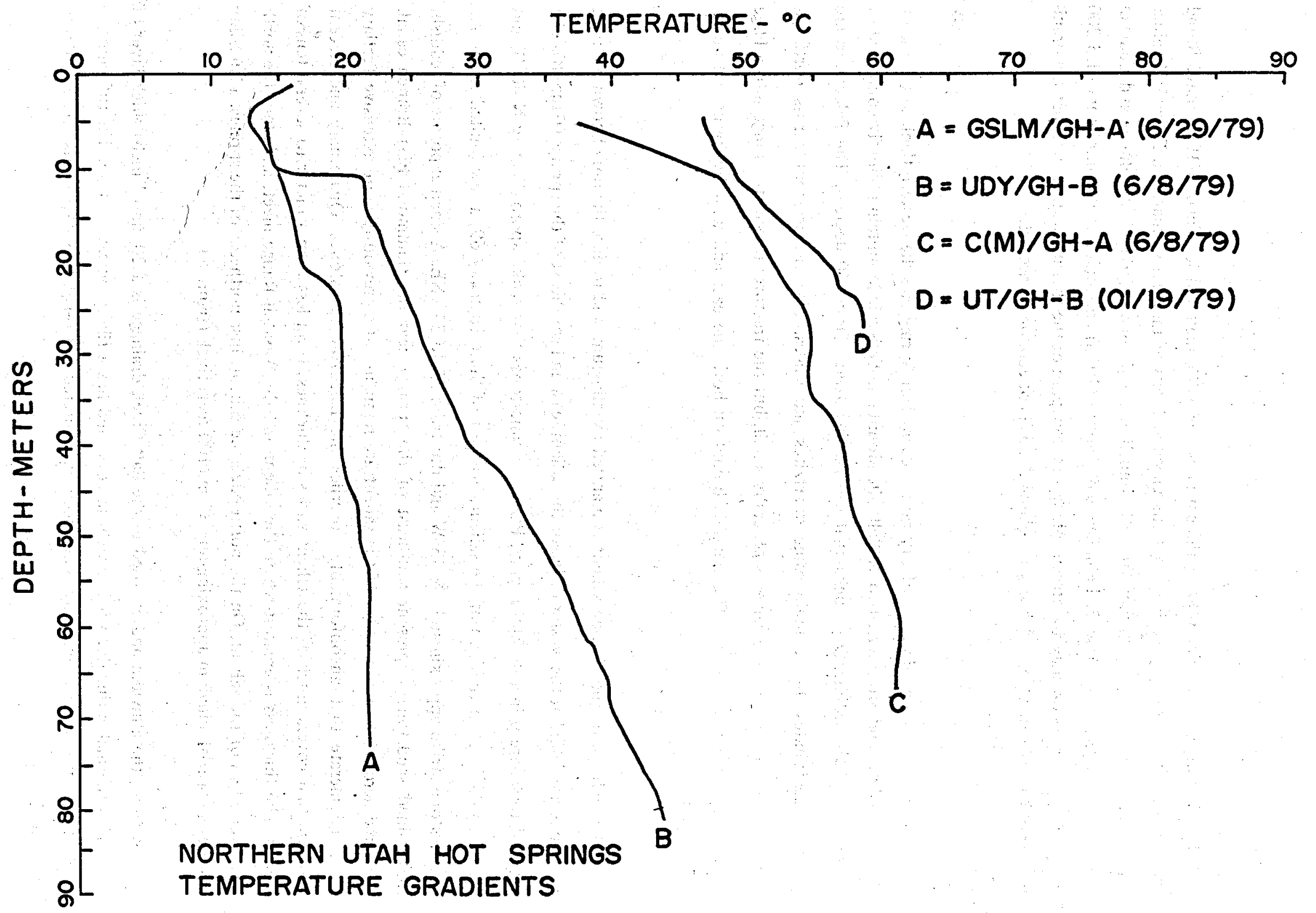

Figure 6 
In addition to the high TDS of the spring water, O'Connell and Kaufmann (1976) have found that Crystal (Madsen) Hot Springs contains elevated levels of radioactive material. Ra and U values for Wasatch Front Springs as taken from O'Connell and Kaufmann (1976) and Felmlee and Cadigan (1978) are presented in table 2. Felmelee and Cadigan (1978) concluded that a minimum of 5,200 metric tons of uranium may be present along the flow path of the thermal waters, and that the uranium may be present in vein and fractures related deposits of economic interest.

Geology

The Wasatch Mountains east of Crystal (Madsen) Hot Springs are the western flank of the Cache Valley syncline, and are referred to as Wellsville Mountain. Wellsville Mountain is chiefly composed of faulted Paleozoic sedimentary rocks that dip northeastward 20 to 60 degrees. The Paleozoics are generally carbonates, but contain some quartzites and shales. The displacement across northeast trending fractures within the range is generally small, but the fractures dissect the range into a large number of small fault blocks. The range is bound on both the east and west by basin and range, normal faults.

The bedrock of the Madsen salient is mantled by alluvium, and to date the only known bedrock exposures are found at the western edge of the salient, east and southeast of the springs (figure 8). The exposed rocks are primarily bluish gray, Paleozoic limestones that strike approximately $\mathrm{N} 40^{\circ} \mathrm{W}$ and dip 60 to $85^{\circ}$ E. Near the base of the salient, just east of State Highway 69, a few limited exposures of limestone strike approximately $\mathrm{N} 43^{\circ} \mathrm{W}$ and dip from 32 to $37^{\circ} \mathrm{NE}$. A small exposure of reddish, fine-grained sandstone is present southeast of the springs near the Hammond East Branch canal. Scattered across the western edge of the salient are remnants of a previously more extensive Tertiary (?) conglomerate that unconformably overlies the Paleozoic limestones. Quaternary and Recent alluvium that covers much of the salient varies in thickness from less than a meter to several tens of meters. The thickness is greatest where the salient and the Wasatch Range meet, and along the north and west edges of the salient. On the north edge the salient, just northeast of the springs, a landslide exposes a scarp of alluvium approximately $30 \mathrm{~m}$ (100 feet) thick (figure 8).

Within the alluvium and exposed in the Salt Creek drainage is a $20 \mathrm{~cm}(7$ inch) thick layer of tufa. This thermal spring deposit is brown in color and has a fibery, vuggy texture. The tufa appears to be laterally extensive and may have been encountered in C(M)/GH-A (Appendix $A$ ) at a depth of $6.7 \mathrm{~m}(22 \mathrm{feet})$. 


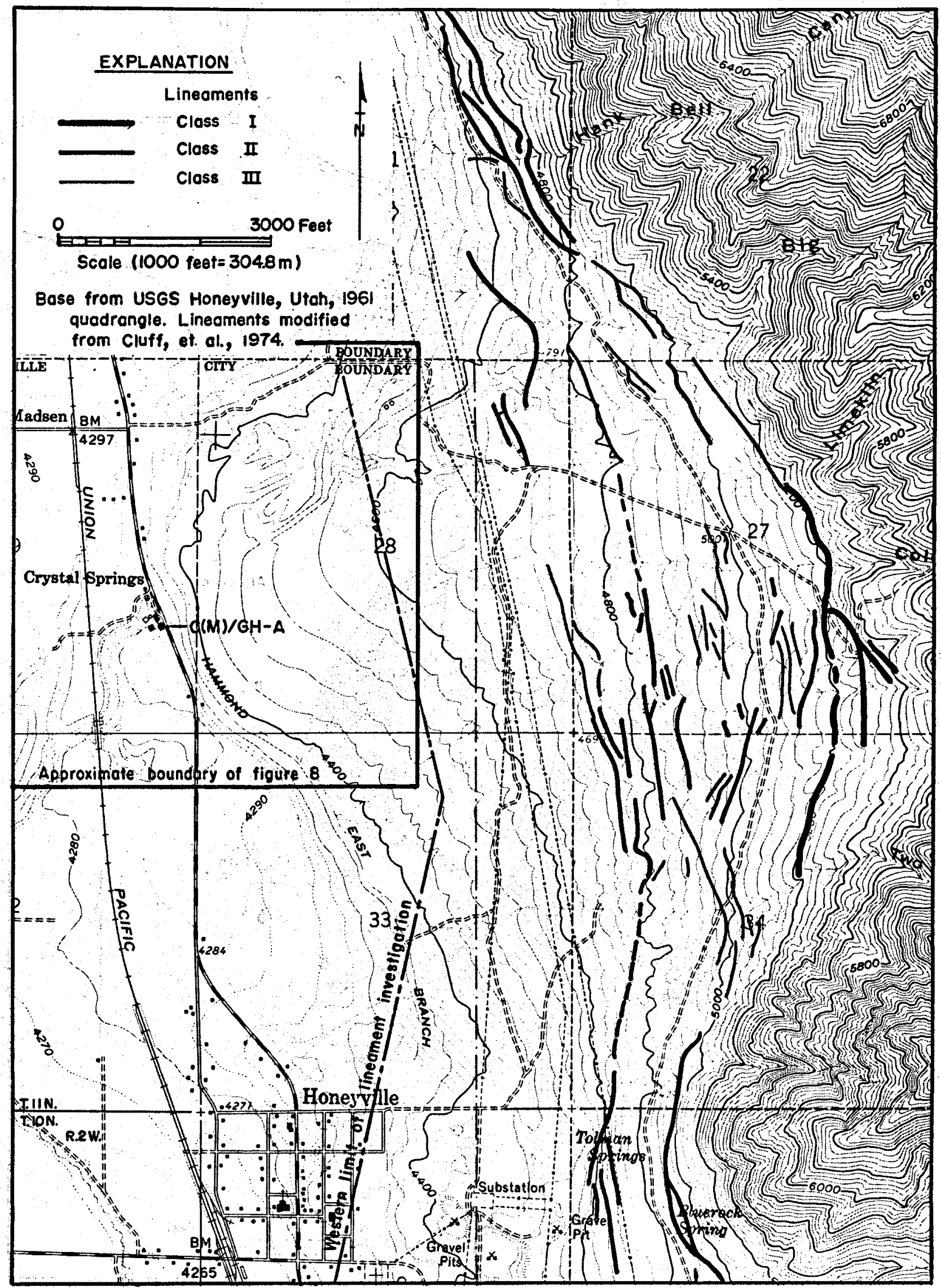

Lineaments of the Madsen Salient, Box Elder County, Utah 
$-18$

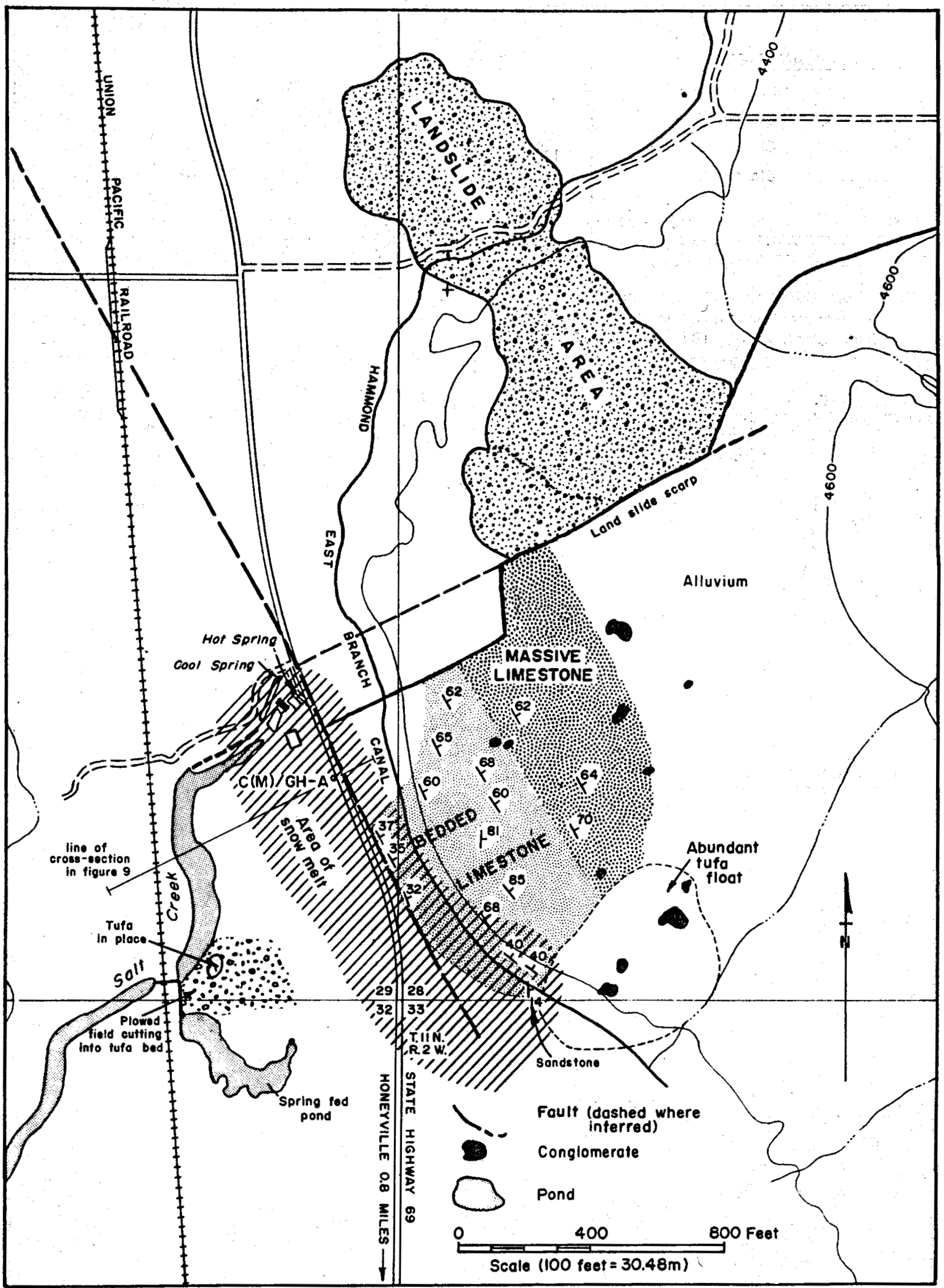

Preliminary geology and structure in the vicinity of Crystal (Modsen) Hot Springs, Box Elder County, Utah 
The Crystal (Madsen) Hot Springs issue at the western base of the Madsen spur or salient. The salient is small relative to the Pleasant View and Salt Lake salients, but is none the less a fault block that is intermediate in elevation between Wellsville Mountain to the east and the graben flow to the west. The prominent west facing scarps (Class I lineaments) in figure 7 are evidence for a fault near the alluvium-bedrock contact. Further west on the salient, a series of north-south trending Class II lineaments traverse the salient and may indicate the presence of at least one additional north trending fault. This second fault is at least in part exposed near Tolman Springs east of Honeyville (figure 7).

The western edge of the salient is also bound by northward striking faults. These faults are likely to be the cause of the steep gravity gradient west of the springs (figure 3). The easternmost of these faults occurrs in the very edge of the salient and is likely to be the conduit for the thermal water that is flowing upward from depth. Evidence for the existence of this fault includes:

1). The depth to bedrock in C(M)/GH-A. Although bedrock is exposed at the surface only a few hundred feet to the southeast of the hole, bedrock was not encountered in this hole unit: 1 a depth of 215 . This sudden change in the depth to bedrock may be a result of displacement across the fault.

2). The apparent change in dip on limestone beds at the toe of the salient (figure 8) relative to dips measured on the salient. The apparent difference in dips may be the result of drag along a normal fault, with the down dropped block to the west.

3). A pronounced lineament observed on areal photography in the soil of a field northwest of the spring. This lineament is on strike of the proposed fault, and may indicate a northwest extension of the feature.

4). The snowmelt pattern observed at the hot spring during the winter of 1978-79. The pattern paralleled the western edge of the salient (figure 7). A fault could act as a linear conduit for the transport of warm water to the near surface.

There is also evidence of northeast trending fractures on the salient. On the northern flank of the salient a series of en echelon faults appear to strike northeastward, away from the springs the most prominent scarp in the series is the one exposed by a landslide (figure 8 ). The other scarps are plainly visible on aerial photography, and dip to the northwest. 


\section{Gradient Hole C(M)/GH-A}

Gradient hole $\mathrm{C}(\mathrm{M}) / \mathrm{GH}-\mathrm{A}$ encountered $65.5 \mathrm{~m}$ (215 ft.) of unconsolidated material over the

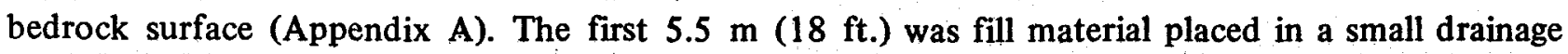
by a former owner of the hot springs. Beneath the fill was approximately 1 meter of fluvial sand and gravels. Once through the gravels drilling became difficult and a white calcareous powder was blown from the hole over an interval of approximately $0.5 \mathrm{~m}(2 \mathrm{ft}$.). A series of sands and gravels were encountered from 7.3 to $65.5 \mathrm{~m}$ ( 24 to $215 \mathrm{ft}$.) with the water table present at approximately $9 \mathrm{~m}$ (30 ft.). At a depth of $65.5 \mathrm{~m}$ (215 ft.) a fractured calcareous sandstone, reddish in color and similar to the sandstone observed on the salient, was encountered. From $69.5 \mathrm{~m}$ ( $228 \mathrm{ft}$.) to a total

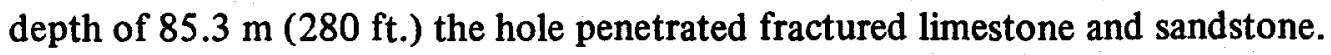

Temperature measurements taken in $\mathrm{C}(\mathrm{M}) / \mathrm{GH}-\mathrm{A}$ are presented in figure 6 . An obstruction blocking the one-inch diameter pipe of the gradient hole required that the gradient be taken in an observation hole placed in the same hole. The temperatures in the hole do not appear to be in equilibrium as in several intervals, minor reversals occur. The pumping of excessive volumes of water from the subsurface may have altered the temperatures significantly and additional time will be necessary for the hole to equilibriate.

The gradient, as presented in figure 6, indicates the hole is under the direct influence of hot water in the subsurface. Temperatures are greatly elevated over temperatures that might be expected at a location not under the influence of thermal waters. Temperature reversals on the curve may indicate the portions of the aquifer having relatively high permeability. The only linear interval of the curve below 50 feet is that from 50 to 90 feet ( 15 to $27.4 \mathrm{~m}$ ) and corresponds to a section of the sand and gravel aquifer.

The Near Surface System - Crystal (Madsen)

The faults bounding the north and western edges of the Madsen salient control the movement of thermal water from the deep system to the near surface system where the water is available at reasonable drilling depths. The main structure along which thermal water is being transported is the major northwest striking fault bounding the western end of the salient (figure 7). The main thermal spring orifice is located at the intersection of the northwest trending fault zone and an element of the northeast striking fault system that bounds the northern edge of the salient. Brecciation of the rock at the intersection of the fault planes has improved the vertical permeability and formed a conduit for transporting large volumes of water to the surface.

The fault intersection is not the only location at which thermal water is leaking from the northwest trending fault. The snowmelt pattern, and minor springs and seeps of thermal water along Salt 
Creek are evidence of the seepage of water into the subsurface along a $300 \mathrm{~m}(1000 \mathrm{ft}$.) length of the northwest striking structure. The snowmelt pattern observed in February and March of 1979 (figure 8) was elongate in a northwest - southeast direction. The area devoid of snow began abruptly in the vicinity of the main thermal spring orifice and extended southward along the western edge of the salient. The western edge of the snow melt pattern was observed to migrate westward through the month of March, but never extended past Salt Creek. Outside the area of snowmelt, approximately 15 $\mathrm{cm}$ ( $6 \mathrm{in}$ ) of snow covered the fields. The warm springs and seeps along the eastern edge of Salt Creek occur at the intersection of the water table and the ground surface. Figure 9 is a generalized crosssection illustrating the geologic and hydrologic relationships at Crystal (Madsen) Hot Springs.

A very generalized cross-section depicting the conditions believed to be present in the subsurface south of the main spring is presented in figure 9. Thermal water moving upward along the fault leaks into the sands and gravels beneath the tufa. This sand and gravel aquifer is unconfined and a water table surface exists a few feet below the tufa. Where the surface drainage (Salt Creek) has removed the more recent alluvium and intercepts the water table, springs issue along the creek banks and creek bottom. In the subsurface, thermal water flows westward beneath the railroad tracks in the sand and gravel aquifer.

\section{UDY HOT SPRINGS}

Description and Water Chemistry

Udy Hot Springs (B-13-3) 23-S, issues to the surface one mile southwest of Plymouth on the flood plane of the Malad River. The springs consist of a number of orifices that form a roughly semicircular pattern on the western flank of the river bottom (figure 10). A large lake containing several spring orifices is the most conspicuous feature of the springs, but a series of smaller orifices given names such as "Indian Pool", "Morning Glory Hole", and "Mud Pots" are present south of the large lake. Water from all of the orifices drains directly into the Malad River.

The springs are no longer referred to as Udy (misspelled on USGS Plymouth 7.5 minute quadrangle, and in Mundorff (1970), as Uddy) Hot Springs. The present owners of the hot springs and surrounding property are developing the area as a resort under the name Belmont Springs Park. The thermal water is used to heat a swimming pool and the resort clubhouse.

In recent years development has extensively modified the natural land surface. Fill material has been extensively used to develop a golf course on the western slope of the river channel and as a result, the spring orifices have been modified slightly. A limestone outcrop reported at one spring orifice by Milligan et.al. (1966) and Mundorff (1970) has been buried. Rough concrete aprons have been poured 


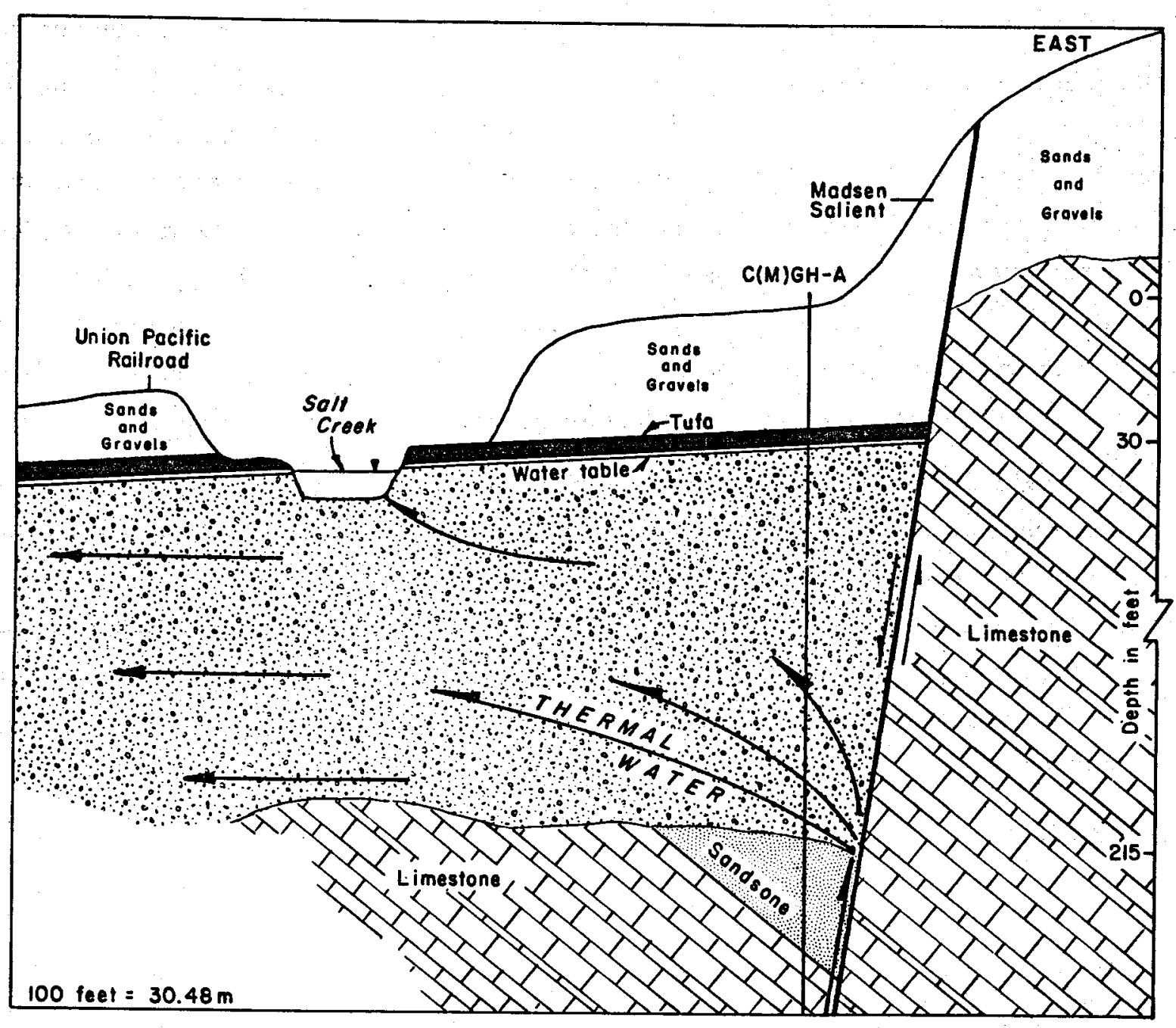

Generalized cross-section of the area south of Crystal (Madsen) Hot Springs, illustrating geologic and hydrologic relationships

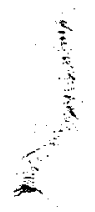

Figure 9 


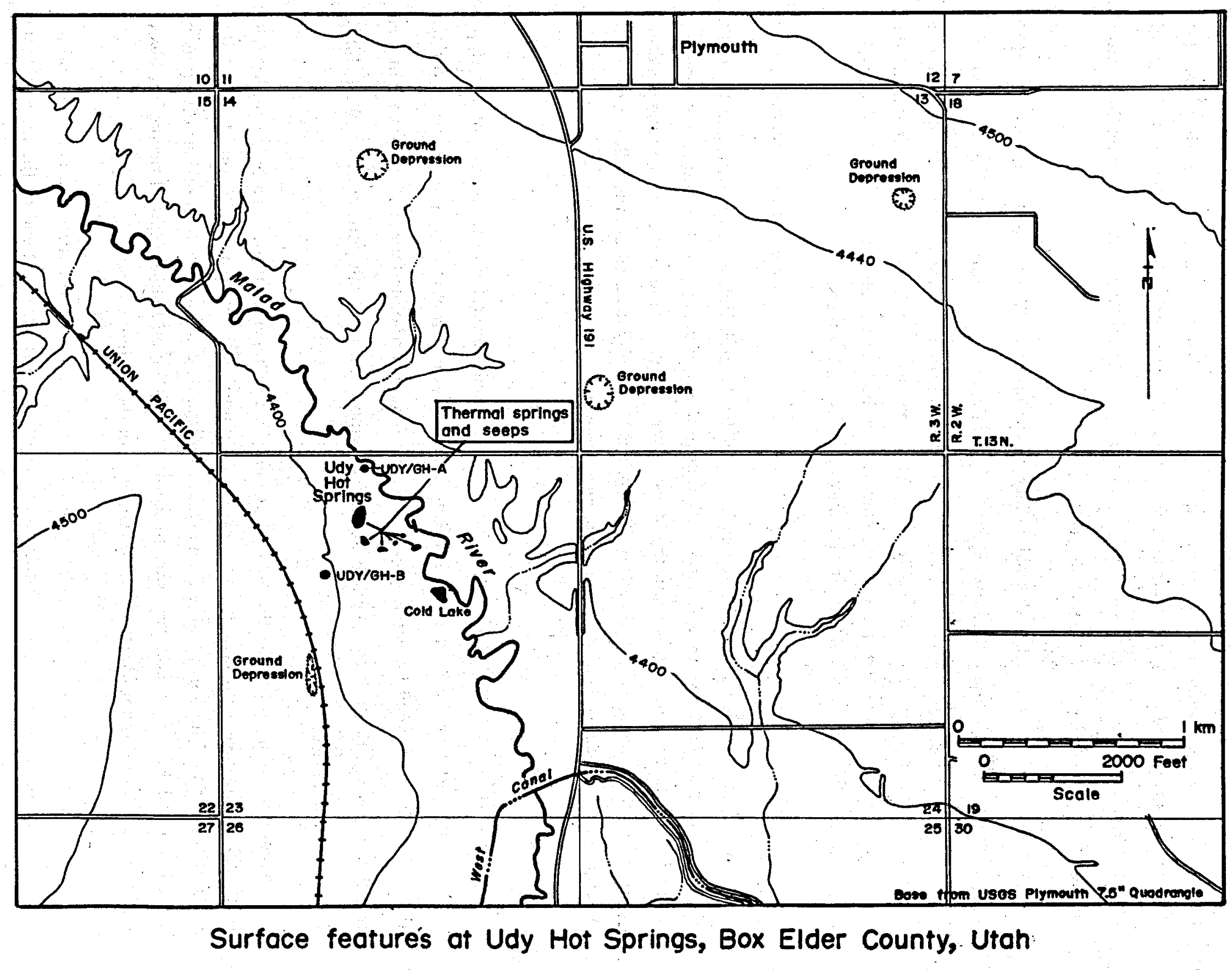

Figure 10 
around a number of ponds in an effort to stabilize the pond banks. Modification of the Malad River channel has made a pond of one channel segment containing a spring orifice, and at the same time exposed a tufa deposit that now forms a riffle in the Malad River. Tufa can also be seen lining several of the smaller ponds including the Morning Glory Hole.

When compared with other thermal springs of the northern Wasatch Front, the quality of the thermal water is moderately good (table 3). With a TDS content of over $8000 \mathrm{mg} / 1$ the water is considered brackish, and almost $90 \%$ of the total dissolved solids are $\mathrm{Na}$ and $\mathrm{Cl}$ ions. Milligan, et.al. (1966) used an estimated flow of $3 \mathrm{cfs}$ to arrive at spring yield estimated at 60 tons of salt per day. As will be discussed later, the spring water may actually be diluted substantially just before reaching the surface and thermal fluids of greater TDS may exist just below the surface.

Geologic and Structural Setting

The Udy Hot Spring system is situated between the Wasatch Range on the east, and West Hills Range to the west. The two ranges, vastly different in terms of geology and structure, are separated by Basin and Range structures beneath the Malad River Valley. Although the geologic and structural relationship of the region surrounding Udy Hot Springs is not fully understood, the following is a brief description of the geology and structure as presently known.

\section{The West Hills}

Bues (1963) recognized both Upper Pennsylvanian and Lower Permian sections of the Upper Oquirrh Formation in the West Hills. The Upper Pennsylvanian rocks are a minimum of 1700 feet thick and consist of sandy limestone, calcareous sandstone or orthoquartzite, and a few beds of sand free limestone. Nearly all of the Oquirrh Formation exposed in the Utah portion of the West Hills is Lower Permian in age.

According to Bues (1963) the West Hills range is the upper plate of a Larimide thrust. The tight folds of the range with axes striking north-south to north-northwest are similar to other Larimide folds of the region. The north end of the range is cut diagonally in a northwest-southeast direction by a pre-Basin and Range structure referred to as the North Canyon Fault. Exposed on the northwest upthrown block of this normal fault is the lower plate of the Larimide thrust.

The West Hills range appears to be cut by a series of east-west structures. Bues (1963) reported two east-west trending structures that form a graben at the northern most end of the range in Idaho but did not report any such structures further south. Areal photography and satellite imagery, how- 


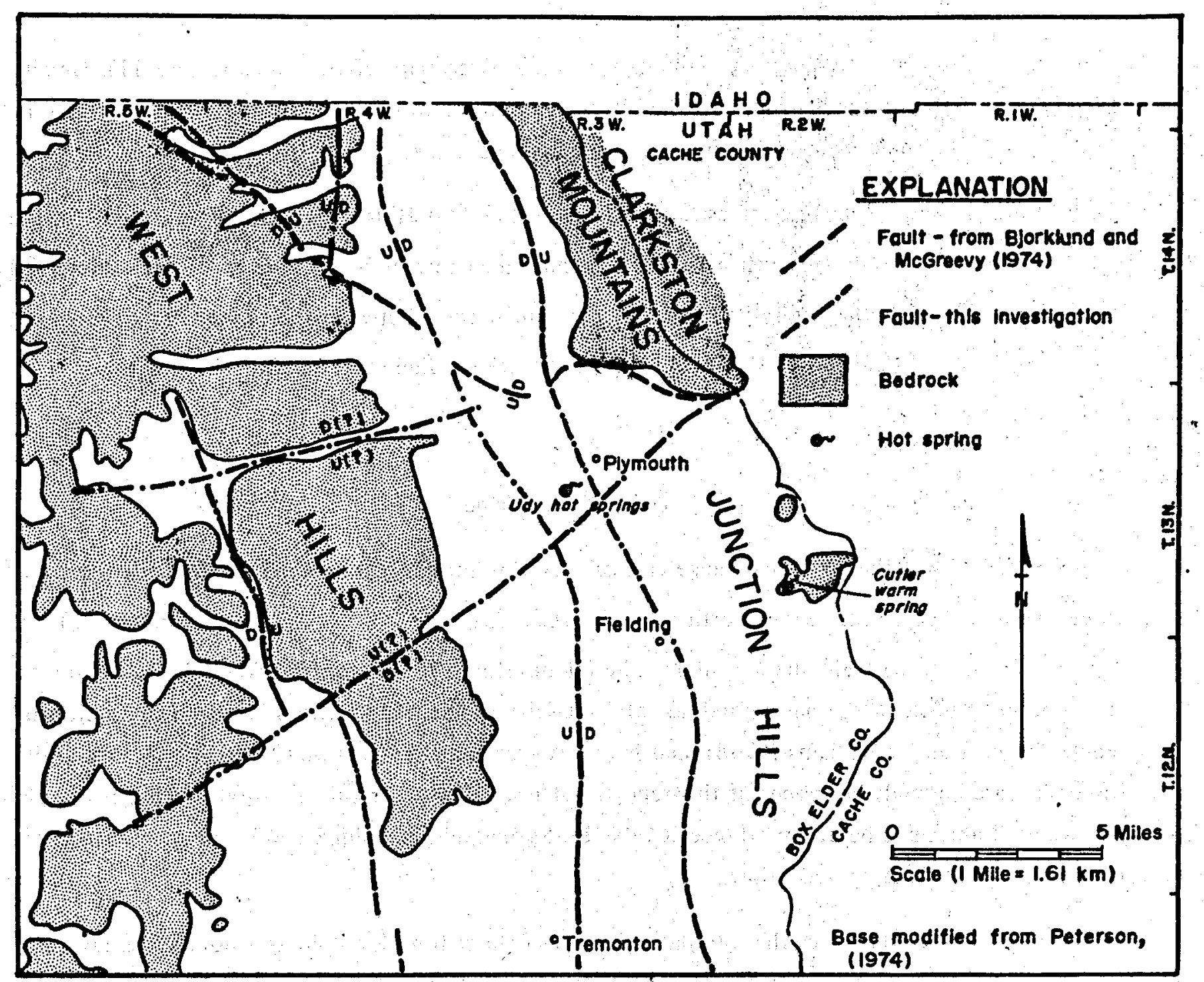

Structures in the vicinity of Udy Hot Springs, Box Elder County, Utah 
ever, show two distinctive east-west trends in the southern part of the range (figure 11). Gravity (Peterson, 1974) data tends to support the eastward extension of the southern most structure into the vicinity of the thermal spring and into the valley graben complex.

Although Bues (1963) describes faults bounding the West Hills range, the best evidence for the range being bound by north-south striking Basin and Range normal faults is the gravity data presented in figure 3. There is no doubt that normal faults are present between the ranges and grabens, but there is some uncertainty as to the bounding fault locations where the relief on the gravity surface is slight (figure 3 ).

\section{The Wasatch Range}

The geology of the Wasatch Range east of Udy Hot Springs is complex, and can be divided into three distinctive segments. From north to south, these segments are: 1) Clarkston Mountain, 2) the Junction Hills, and 3) Wellsville Mountain. The relationship of Clarkston and Wellsville Mountains to the Junction Hills, and the nature and age of fault separating these segments has been the subject of lengthy discussion by Williams (1948), and is briefly mentioned by Hanson (1949). The details of the discussion are beyond the scope of this report, but insomuch as certain structural trends observed in the Wasatch appear to be of importance at Udy Hot Springs a brief summary of geology and structure of these segments is presented below.

Hanson (1949) describes the internal structure of Clarkston Mountain as a homocline having an average strike of $\mathrm{N} 30^{\circ} \mathrm{W}$ and an average dip of $30^{\circ} \mathrm{NE}$. The range, composed of Cambrian and Ordovician age rocks, is traversed by numerous faults that cut the mountain into many blocks varying greatly in strike and dip. The range is bound on both the east and west by normal Basin and Range type faulting that give the range its present relief as a horst between the grabens of the Wasatch Front and the Cache Valley. At the south terminus, the range is separated from the Junction Hills by a fault referred to by Hanson as the Junction Hills fault.

Wellsville Mountain is described by Williams (1948) as a homocline striking $\mathrm{N} 30^{\circ} \mathrm{W}$ and dipping $30^{\circ} \mathrm{NE}$. The internal structure is essentially the same as that of Clarkston Mountain, howerver, the rocks exposed in the range are Cambrian to Mississippian in age and are less intensely fractured than those of the Clarkston range. Basin and Range age normal faults bound Wellsville Mountain on the east and west. Although evidence for east-west normal faulting at the north end of Wellsville Mountain is not conclusive, Williams (1948) indicates a fault in this area. 
The Junction Hills, cresting 3,000 feet below the ranges to the north and south, consists of northwestward dipping Paleozoic rocks mantled by a variable thickness of Tertiary sediments. The Paleozoic rocks are exposed in only very limited areas, but Williams (1948) indicates that the rocks become progressively older from north to south and describes the basic structure of the Junction Hills as a northwest dipping homocline. In addition to the topographic relief between the Junction Hills and the boarding ranges, extreme stratigraphic relief is also indicated. Williams (1948) reports that there is 7,000 or 8,000 feet of stratigraphic separation between formations in the Junction Hills and the Wellsville Range. Hanson indicates a minimum of 10,000 feet of stratigraphic separation between the Hills and Clarkston Mountain. Although faults have been mapped at both the north and south ends of the Junction Hills, it is highly unlikely that 8,000 to 10,000 feet of throw exist across these faults, and Williams (1948) proposes 5 models in an effort to explain the structural relationships of the area. Normal faults bounding the eastern and western edges of the Junction Hills are Basin and Range structures, and maybe southern extensions of Plymouth and Clarkston faults bounding Clarkston Mountain (Hanson 1948).

\section{The Malad River Valley Graben System}

Between the West Hills and the Wasatch Range is a complex graben system buried beneath the valley alluvium. The gravity contours in figure 3 give some indication of the nature of the graben including the location of bounding faults and an estimate of alluvium thickness. As described earlier, Udy Hot Springs is located over a gravity high. To the north of the hot springs and west of Clarkston Mountain is a narrow but relatively deep closed graben. Using an alluvium-bedrock density contrast of $0.5 \mathrm{gm} / \mathrm{cc}$, Peterson (1974) estimated the maximum thickness of alluvium in the graben to be 1500 feet. Using Peterson's (1974) gravity data, Bjurklund and McGreevy (1974) located a number of bounding faults (figure 11) including those bounding the narrow graben. South of the hot springs and west of the Junction Hills a narrow, relatively shallow graben opens southward into the main graben south of Tremonton and west of Willard and Ogden.

Surficial Geology

Apart from the description of the West Hill present above, there is little in terms of geology in the immediate vicinity of the hot springs that is informative on conditions existing in the subsurface. Surficial deposits in the vicinity of the spring are Quaternary Lake Bonneville deposits consisting of lakeshore, fan and delta deposits and interbedded alluvium and colluvium (Bjorklund and McGreevy, 1974). A series of three depression in the surficial materials (figure 10) form a northeast striking lineament parallel to the lineament observed in the canyon in the West Hills southwest of the springs 
(figure 11). The origin of the depressions is unknown, but none are known to exist south of the lineament. One depression is present north of the lineament.

Very few bedrock outcrops have been reported in the vicinity of the springs. Mundorff (1970) reported the presence of a limestone outcrop on the western bank of the Malad River, thermal springs issued at the base of the outcrop. The outcrop is no longer visible as modification of the land surface has buried any outcrop that may be present. Two and one-half miles southwest of the springs, (B12-12)ddc, at the intersection of two drainages is an outcrop of the Tertiary Salt Lake formation consisting of volcanic tuff. Due west of this outcrop, is a small outcrop of the Oquirrh formation (Bjorklund and McGreevy, 1974).

\section{Shallow Ground Temperature Survey}

In August of 1978 a shallow ground temperature survey was undertaken at Udy Hot Springs. A series of 40 holes, 1.4 meters deep, were augered in the vicinity of the springs, a length of pvc pipe . was inserted into the hole and the annulus between the pipe and the hole was back filled. After sufficient time had passed for the augering induced temperature affects to dissipate the temperature in the bottom of each hole was measured.

The results of the temperature survey were quite surprising as the measured temperates varied from a maximum of $32.6^{\circ} \mathrm{C}$ to a minimum of $16.9^{\circ} \mathrm{C}$. The minimum temperatures were recorded east of the Malad river where the average temperature was $17.4^{\circ} \mathrm{C}$ with a standard deviation of 0.4 . The average temperature west of the river was $21.8^{\circ} \mathrm{C}$ having a standard deviation of 3.64 . Three temperatures of $30^{\circ} \mathrm{C}$ or greater were measured, and these temperatures were recorded only a few feet from a major spring orifice.

Ground temperatures in the vicinity of the springs may be considered slightly elevated if measurements east of the river are considered to be normal for late summer ground temperatures. However, the $4.4^{\circ} \mathrm{C}$ difference between average temperatures on opposite sides of the river is not considered large. Since minor differences in ground temperatures can be induced by many factors (Olmsted, 1977), no attempt has been made to correlate minor temperature variations with possible structures at depth such as done at Crystal Hot Springs in Salt Lake County, Utah by Murphy and Gwynn, (1979).

There are three factors that may be contributing to the relatively minor variations in ground temperatures in the vicinity of the springs.

1) Considerable thicknesses of clay were encountered in the two gradient holes drilled to the 
Table 4. Temperature and conductivity measurements, at the Morning Glory Hole and UDY/GH - A Udy Hot Springs, Box Elder County, Utah.

\begin{tabular}{lccccc}
\hline & Morning Glory Hole & \multicolumn{3}{c}{ UDY/GH-A } \\
\hline Date & $\begin{array}{c}\text { Temp. } \\
{ }^{\circ} \mathrm{C}\end{array}$ & $\begin{array}{l}\text { Conductivity } \\
\mu \text { mohs } / \mathrm{cm}^{\circ} @ 25^{\circ} \mathrm{C}\end{array}$ & Date & $\begin{array}{c}\text { Temp. } \\
{ }^{\circ} \mathrm{C}\end{array}$ & $\begin{array}{c}\text { Conductivity } \\
\mu \text { mohs } / \mathrm{cm}^{\circ}\left(25^{\circ} \mathrm{C}\right.\end{array}$ \\
\hline \multirow{2}{*}{$1 / 23 / 79$} & 49.5 & $1.44 \times 10^{4}$ & $1 / 22 / 79$ & 18.8 & - \\
& & & $1 / 23 / 79$ & 19.0 & $9.5 \times 10^{2}$ \\
& & & $3 / 5 / 79$ & 20.4 & $5.5 \times 10^{3}$ \\
& & $6 / 8 / 79$ & 27 & $8.6 \times 10^{3}$ \\
\hline
\end{tabular}

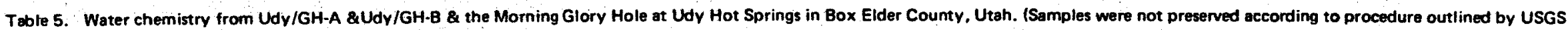
and should be used for general comparison.

\begin{tabular}{|c|c|c|c|c|c|c|c|c|c|c|c|c|c|c|c|c|c|}
\hline $\begin{array}{l}\text { Owner or } \\
\text { Name }\end{array}$ & Depth & $\begin{array}{r}\text { Date of } \\
\text { Collection }\end{array}$ & $\begin{array}{l}\text { Refer } \\
\text { ence }\end{array}$ & $\mathrm{SIO}_{2}$ & $\mathrm{Fo}$ & ca & Mg & $\mathrm{Na}$ & K & $\frac{\mathrm{HCO}_{3}}{\mathrm{mg} / 1}$ & $\mathrm{SO}_{4}$ & CI & $\mathrm{No}_{3}$ & $F$ & TDS & $\begin{array}{l}\text { Cond. } \\
\text { mmno }\end{array}$ & $\begin{array}{c}\mathrm{PH} \\
\because \\
\end{array}$ \\
\hline $\begin{array}{l}\text { Wendell } \\
\text { Welling }\end{array}$ & Surface & $3-9-78$ & UGMS & 25.0 & 0.05 & 220.0 & 73.0 & 2,800 & 14.0 & 362 & 102 & 5,025 & 0.15 & 1.20 & 9,080 & 13,060 & 8.3 \\
\hline $\begin{array}{l}\text { UDYI } \\
\text { GH.A }\end{array}$ & 130 & $1-26-79$ & UGMS & 71 & - & 35 & 7 & 170 & 29 & 358 & 38 & 108 & 0.10 & 1.50 & 602 & 970 & 8.1 \\
\hline $\begin{array}{l}\text { UDYI } \\
\text { GH-A }\end{array}$ & 130 & 3-06-79 & $\begin{array}{l}\text { UGMS } \\
\text { SH }\end{array}$ & 75 & - & 200 & 73 & 725 & 78 & 338 & 49 & 1.480 & - & - & 2,930 & 4,850 & 7.6 \\
\hline $\begin{array}{l}\text { UDYI } \\
\text { GHAA }\end{array}$ & 130 & $7-10-79$ & UGMS & - & - & 220 & 73 & 1,590 & 120 & - & 63 & 2,825 & - & 1.00 & 5.320 & 9,120 & - \\
\hline $\begin{array}{l}\text { UDYI } \\
\text { GH-B }\end{array}$ & 280 & $3-06-79$ & UGMS & 25 & - & 200 & 61 & 2,707 & 134 & - & 140 & 4,200 & - & - & 7.080 & - & - \\
\hline
\end{tabular}


north and west of the springs. Clay has a low thermal conductivity and inhibits the conductive flow of heat from below.

2) The conduits that transport the thermal fluids from depth to the surface may be well established and little if any hot water escapes into surrounding near surface aquifers.

3) The permeable near surface artesian aquifer encountered in UDY/GH-A influences the observed ground temperatures by

a) transporting relatively cool water into the vicinity of the spring thus masking the conductive temperature affects produced by warmer water at depth, and

b) preventing thermal waters from flowing laterally away from the spring.

Gradient Holes

Two thermal gradient holes were drilled by UGMS at Udy Hot Springs during the winter of 1978-79. A third hole originally planned for the area was not drilled due to adverse weather conditions and problems encountered during the drilling of UDY/GH-A and UDY/GH-B. Both holes provided valuable subsurface geologic and hydrologic data.

The first hole drilled, referred to as UDY/GH-A, was spuded near the entrance to the resort, approximately 500 feet north of the large lake associated with the hot springs (figure 10). After penetrating 40 feet of clay, 50 feet of fine sand, and an additional 30 feet of clay, the hole encountered saturated sand and gravel at a depth of 120 feet. While an additional 10 foot joint of drill steel was added to the drill stem, a small artesian flow was observed at the collar of the hole. When the hole was advanced to 130 feet a flow of over $200 \mathrm{gpm}$ issued from the hole. Initial measurements indicated that the water temperature was $18.6^{\circ} \mathrm{C}$ and had a conductivity of $9.5 \times 10^{2} \mu \mathrm{moh} / \mathrm{cm} @ 25^{\circ} \mathrm{C}$. After one week, the owners of the spring noticed an increase in salt content and temperature. A summary of temperature and conductivity measurements taken since the hole began to flow is presented in table 4 results of water analyses on samples from UDY/GH-A are presented in table 5 . The water in the hole 6 weeks after the flow began is in many respects similar to the thermal spring water.

To date, the hole continues to flow and the water is used by the owners of the Belmont Springs Resort. The owners have lowered a small diameter pipe to the bottom of the hole and reported that the water that flowed from the pipe was less saline and lower in temperature than the total flow. An interpretation of the hydrologic conditions at Udy based on the above observations is presented later in this report. 
The second hole at Udy Hot Springs, UDY/GH-B, was sited west of the hot springs 80 feet above the river bottom (figure 10 ). The site was moved to this position to avoid the problems associated with artesian flow encountered when drilling UDY/GH-A.

Hole UDY/GH-B encountered $30.5 \mathrm{~m}$ (100 feet) of clay before drilling through a $1.5 \mathrm{~m}$ (4 feet) thickness of sand that contained $23.3^{\circ} \mathrm{C}$ water. The sand may be the equivalent of the $15 \mathrm{~m}(50$ feet) thickness of sand in UDY/GH-A. Below (105 feet) the hole was tight and water had to be pumped into the hole in order to keep the clay returning to the surface. Below ( 215 feet) the proportion of course elastic material increased, and altered tuff was mixed with the clays in the bottom (25 feet) of the hole.

The temperature $\log$ for UDY/GH-B (figure 6) is somewhat irregular but a straight line fit through the curve yields a gradient of $330^{\circ} \mathrm{C} / \mathrm{km}$. A gradient of this magnitude does not reflect the normal geothermal gradient of the area, but rather is a product of moderately high temperature water at shallow depth covered by low conductivity clays. For example, the observed gradient could be produced by $50^{\circ} \mathrm{C}$ water at a depth of $100 \mathrm{~m}$ (330 feet) or $100^{\circ} \mathrm{C}$ water at a depth of $253 \mathrm{~m}$ (830 feet) assuming the thermal conductivity of interviewing material remains constant.

\section{The near-surface hydrogeologic system}

A greatly simplified model of the hydrologic system in the vicinity of Udy Hot Springs is presented in figure 12. The model is an attempt to explain the time dependent variations in water chemistry and temperature observed in UDY/GH-A in a manner consistent with the known geology of the area. The model is not a detailed geologic cross-section.

The model as portrayed in figure 12 consists of a permeable sand and gravel aquifer of unknown thickness overlain by a relatively impermeable and variable thickness of clay. Within the clay are large saturated sand bodies of limited areal extent that are more or less isolated within the impermeable clay. The permeable sand and gravel aquifer is regional in nature, and is believed to be the aquifer described by Bjorklund and McGreevy (1974) for the Central Plains region of the lower Bear River. Ground water in this aquifer flows into the vicinity of the spring from the east under the influence of the westward sloping potentiometric surface defined by Bjorkland and McGreevy (1974). Lithologic data from UDY/GH-B indicates that the principle aquifer is not present or very thin to the west of the springs, and that the aquifer may terminate against a north-south trending structure associated with the structures transporting the thermal water to the surface. The main sand and gravel aquifer is a confined system, and strong artesian conditions exist in the vicinity of the springs. 


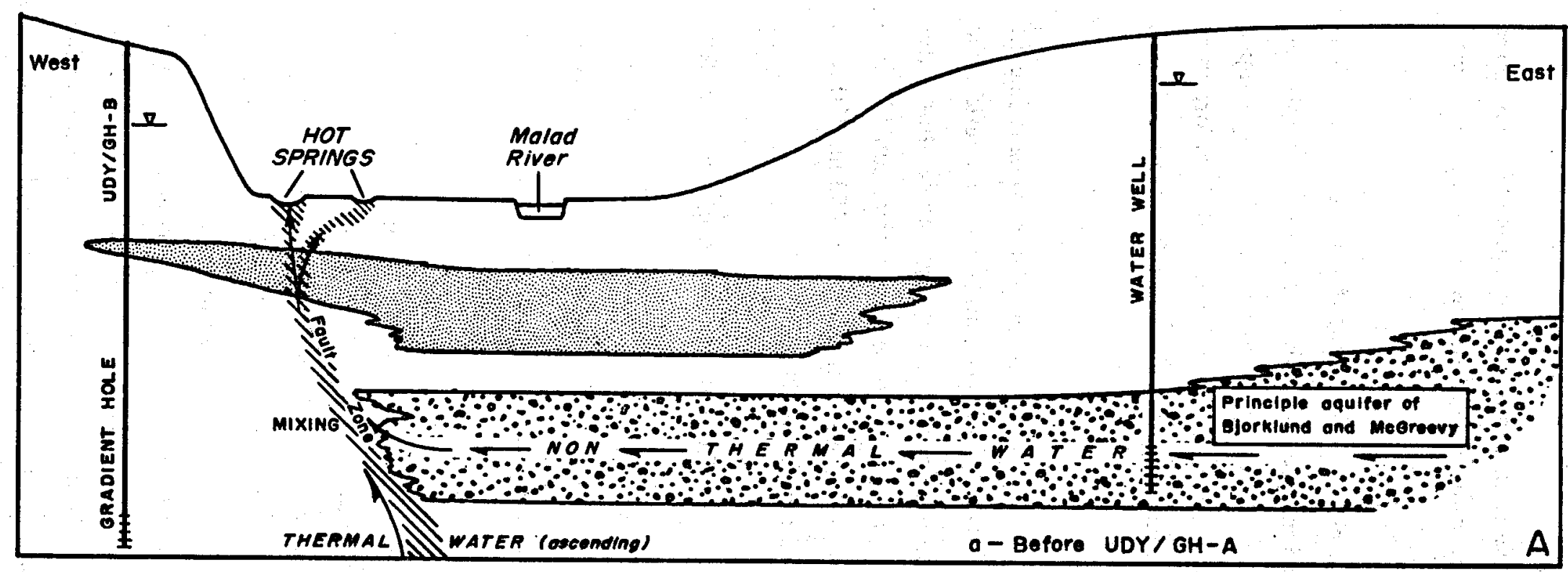

$\dot{\omega}$

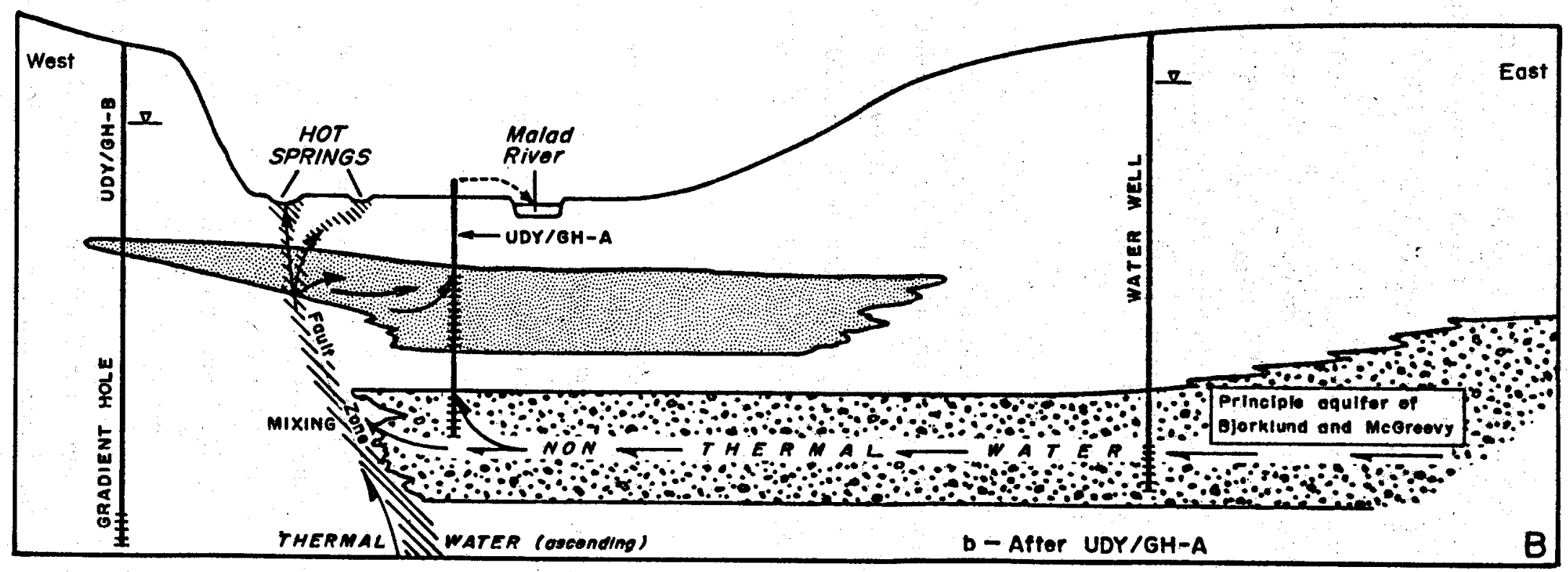

A model of hydrologic relationships at Udy Hot Springs, Box Elder County, Utah

Figure 12 
Prior to any drilling activities by UGMS the condition presented in figure 12 a prevailed. Water from the principle aquifer mixed with the thermal waters and the resulting water mixture rose to the surface through weaknesses in the clay. Although some thermal water might have entered the overlying sand wedge, the wedge was essentially sealed by the clay and the thermal water could not displace the water already present in the sand lens.

When UDY/GH-A was drilled, the hydrologic conditions were slightly altered (figure $12 \mathrm{~b}$ ). Non thermal water from the principle aquifer immediately flowed from the bottom of the hole in large volumes. At the same time, the head in the sandy body was lowered allowing thermal water to flow in the direction of the hole through the sand body. The increasing temperature and conductivity of the water flowing from the hole is an indication that component of thermal water reaching the hole through the sand has increased with time. The component of thermal water mixing with the principle aquifer water in the hole should reach a maximum that is dependent upon the permeability of the sand body.

One very important implication of this model is that the maximum temperature of the geothermal system might be significantly higher than any of the measured temperatures. Although to date there has been no direct indication of much higher temperatures in the near surface, if mixing is indeed occurring, higher temperatures should be anticipated below the zone of mixing.

\section{LITTLE MOUNTAIN-SOUTH GEOTHERMAL AREA}

Description

The Little Mountain geothermal area is about $24 \mathrm{~km}$ ( 15 miles) west of Ogden on the eastern shore of the Great Salt Lake. Bear River Bay flows into the Great Salt Lake immediately west of the area. Little Mountain is a triangular shaped exposure of Precambrian rock that strikes north-south. Elevations are greatest at the southern end of the mountain and decrease northward until only a few low lying outcrops are visible at the surface. The mountain is surrounded by valley fill that extends for miles in all directions. West of the mountain the valley fill is covered by solar evaporating ponds and the Great Salt Lake.

The solar evaporating ponds (figure 13) are part of the Great Salt Lake Mineral Corporation's (GSLM) salt processing plant. Buildings for the GSLM plant are located on the northeastern flank of Little Mountain. Other developments in the area include a newly constructed American Zirconium plant, and a Hill Air Force Base facility, both at the southern end of the mountain. 


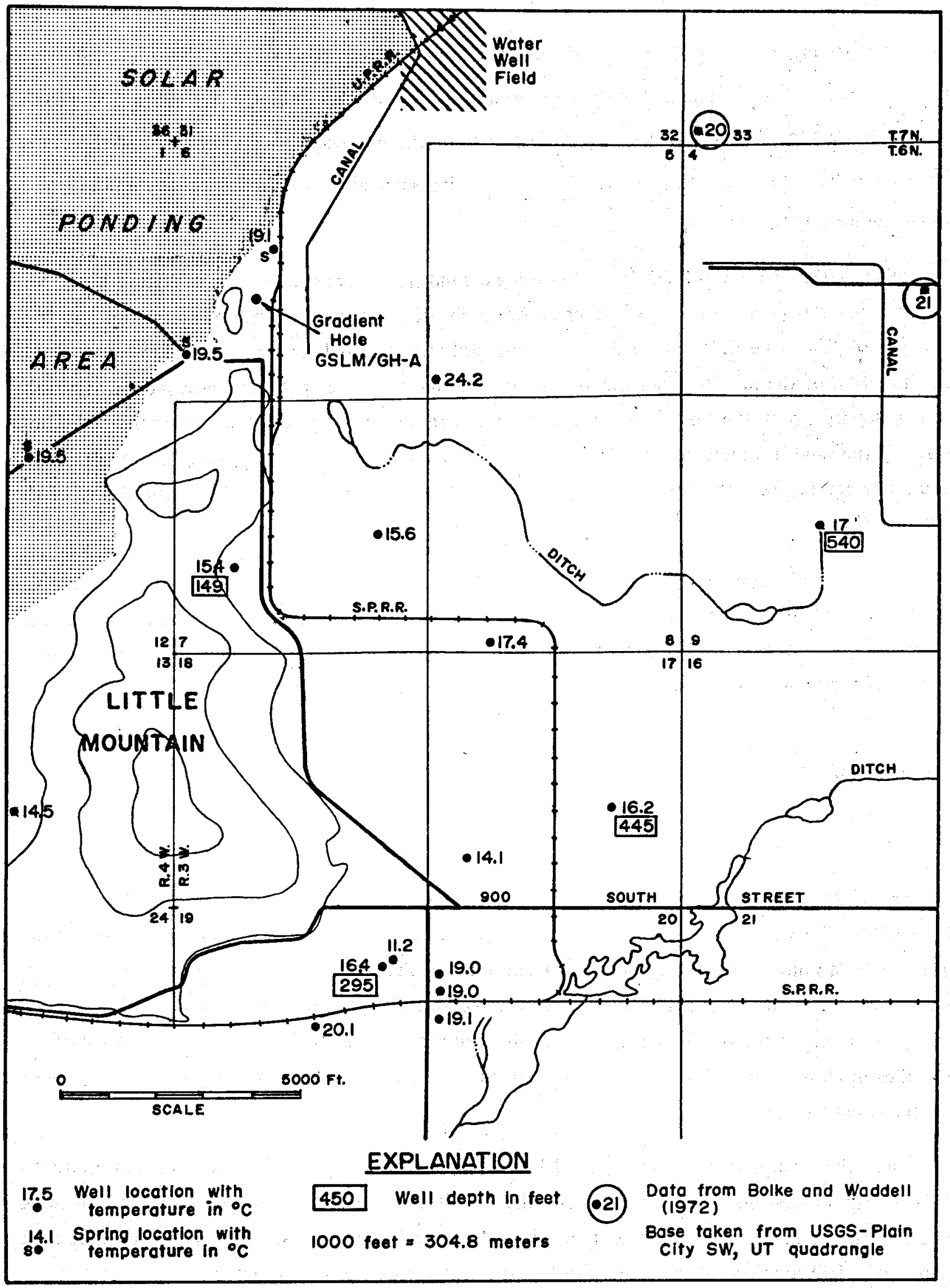

Water temperatures of springs and flowing wells in the vicinity of Little-Mountain-South, Weber County, UT. 
There are no major thermal springs at the Little Mountain geothermal site, but numerous shallow flowing wells and cold springs are present. Many, but not all, of these water sources are indicated on USGS topographic quadrangles for the area, and a number of fresh water springs have been reported within the solar ponds. The flowing wells and springs are a result of the artesian conditions that generally prevail throughout the valley fill aquifers. Water temperatures of the shallow flowing wells (figure 13) and springs, measured in early November, vary from 14.5 to $20^{\circ} \mathrm{C}$. In general, the water temperatures are greatest at the north and south end of Little Mountain, and cooler directly east and west of the mountain. Very little well completion information is available on these abandoned wells, but well depth is indicated where known.

Approximately 12 wells drilled by GSLM for fresh process water are located northeast of the plant (figure 14), and range in depth from 122 to $280 \mathrm{~m}$ (400 to 920 feet). A schematic summary of GSLM well data compiled by Bolke and Waddell (1972) is presented in figure 15 and illustrates the following relationships. The wells penetrate valley fill consisting of alternating sands and clays and have completed in four water producing zones. Only one of the holes was drilled to bedrock. In general, the temperature and TDS of the water increase with depth; reaching maximums of $39^{\circ} \mathrm{C}$ and $980 \mathrm{mg} / \mathrm{l}$ respectively in the zone adjacent to the bedrock surface. All of the holes are artesian, and the static water level generally increases with depth. Holes to the southeast of the main well field (well B, C and D in figure 15) are not as warm as those completed at the same depths in the main well field.

About $4 \mathrm{~km}$ to the west of the main well field (figure 14) a single well of approximately $270 \mathrm{~m}$ (900 feet) in depth encountered water of approximately $33^{\circ} \mathrm{C}$. The addition of this well to those reported by Bolke and Waddell (1972) gives an indication of a possible east west trending zone of elevated temperatures.

Water Chemistry

The chemistry of the warm water at Little Mountain is similar to the water chemistry as described by Waddell and Bolke (1972) of the valley fill aquifer east of Little Mountain. The TDS content is generally less than $1000 \mathrm{mg} / \mathrm{l}$ and the predominant ions are bicarbonate, sodium and chloride. Water heated by deep convection is usually much higher in TDS than the prevailing ground water. Waddell and Bolke (1972) suggest that the warm water observed in the holes at Little Mountain is near surface aquifer water heated by conductive heat transfer and not by mixing with warm saline water. The saline thermal water may issue along a buried fault and be forced to flow laterally by relatively impermeable confining zones in the valley fill aquifer, remaining separated from the aquifer above the confining zone. 


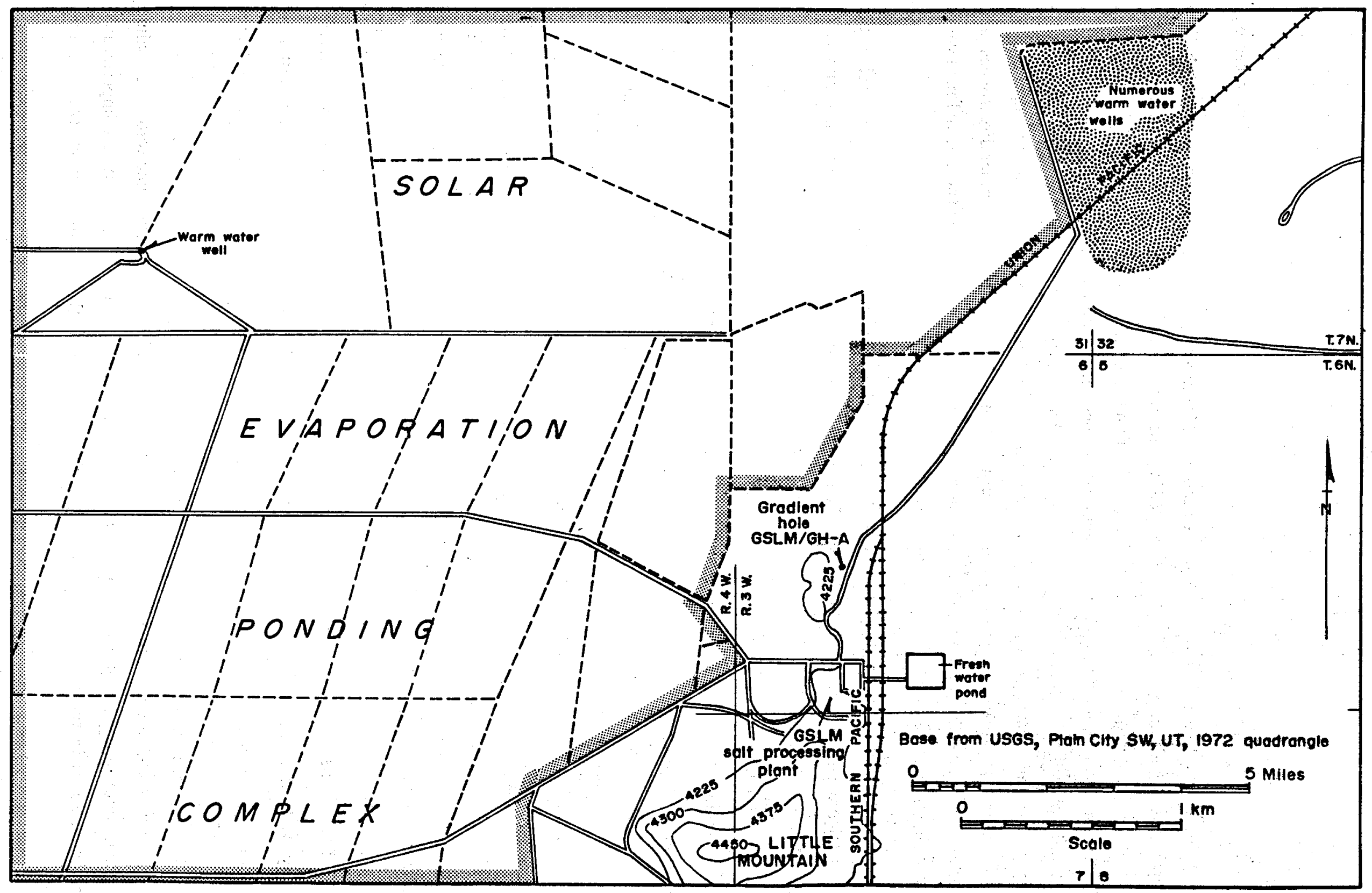

Locations of warm water wells and GSLM/GH-A at Little Mountain, west of Ogden, Weber County, Utah.

Fir're 14 $C$ 


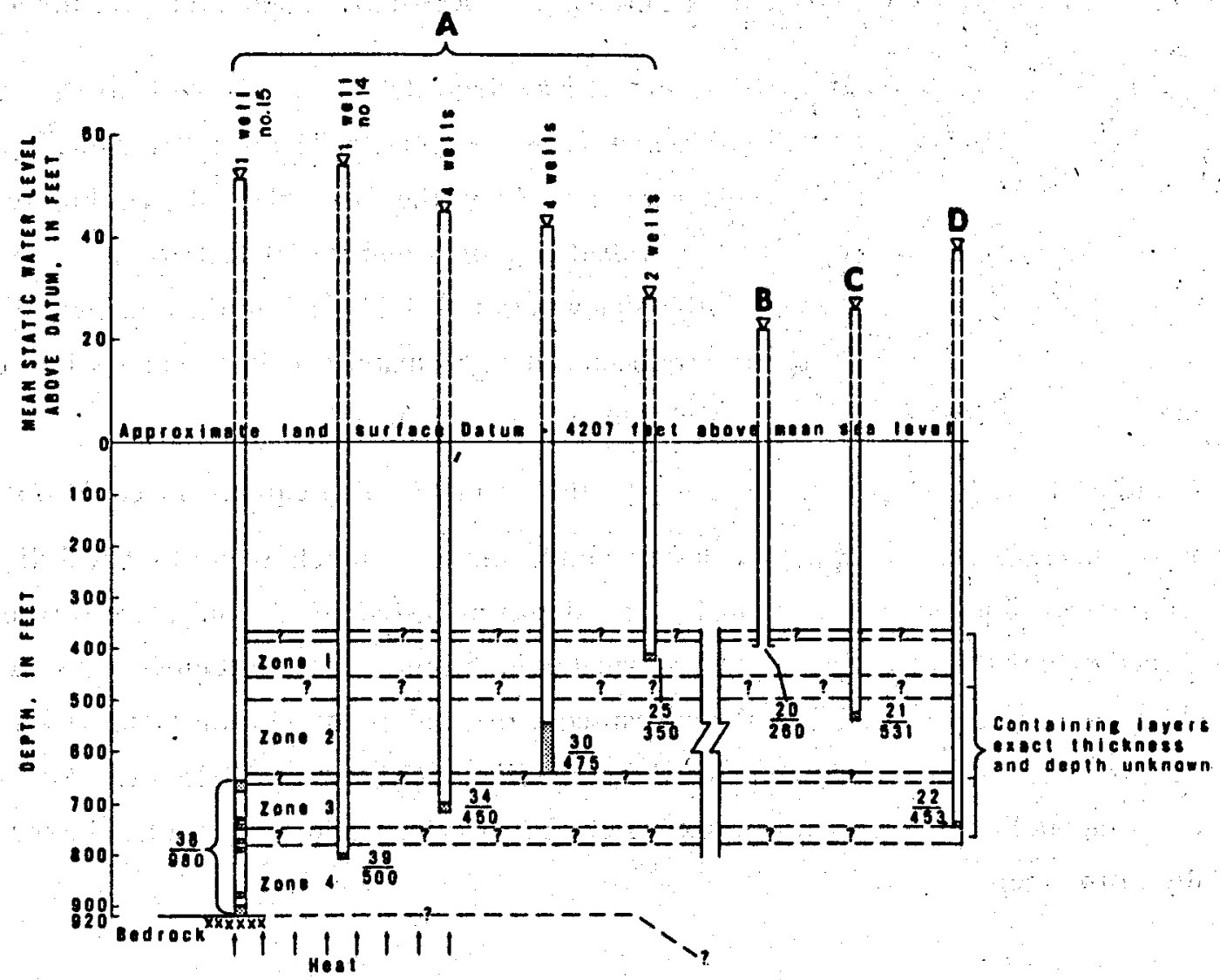

\section{EXPLANATION}

- Number of wells for which average hydrologic data are reported

8 Average static water level

Screened or perforated zone for one or more wells

Jlopen-end casing

Upper number indicates average temperature, in degrees Celsius. 25 for the zone

350 Lower number indicates average dissolved-solids content. in milligrams per liter, for the zone

Figure 15. Schematic diagram showing the water-bearing zones near Little Mountain and some chemical and physical properties of the water. Water analyses for wells 14 and 15 in table 1. Modified from Bolke and Waddell, 1972. 


\section{Gradient Hole GSLM/GH-A}

In an effort to determine if the thermal gradient in the vicinity of Little Mountain was greater than normal, a thermal gradient hole (GSLM/GH-A) was drilled near the northern end of the mountain. Basic data for GSLM/GH-A includes a lithologic in Appendix A and a temperature log in figure 6.

GSLM/GH-A encountered a thin veneer of lake deposits and weathered bedrock before entering tillite. The same tillite is exposed about $30 \mathrm{~m}$ west of the drill site. The bedrock is highly fractured and at certain depths the hole had a tendency to cave. When the first hole collapsed before the one inch pipe could be installed, a second hole was drilled approximately 10 feet to the west. The second hole encountered similar problems but the pipe was installed. A bend in the one inch pipe at approximately $27 \mathrm{~m}$ (90 feet) is believed to have been caused by material collapsing back into the hole after the pipe had been installed but before back filling was completed.

Because of the bend in the one inch pipe the normal logging equipment could not be used, and logging of the hole was done with a thermocouple and a Campbell Scientific CR-5 digital recorder. Temperatures do not increase uniformally with depth in GSLM/GH-A, and there is some question as to whether or not the hole had reached thermal equilibrium when the temperatures were measured. The extended period of drilling may have caused a thermal disequilibrium from which the hole had not yet recovered. The two segments of the curve (figure 6) between 10-20 meters and 40-55 meters define a straight line gradient of approximately $130^{\circ} \mathrm{C} / \mathrm{km}$, while temperatures below $55 \mathrm{~m}$ are essentially isothermal.

Summary

UGMS investigations at Little Mountain have not detailed the controls on the geothermal system, but have provided interesting results that may be useful in future investigations. Previous investigators have assumed the thermal water issues along a north-south striking fault bounding the eastern edge of Little Mountain. The temperature of water flowing from area wells may indicate that the fault strikes east-west, and that a second area of warm water may exist at the southern end of the mountain. The gradient in C(M)/GH-A is approximately 4 times the gradient considered normal for Basin and Range, but the material in which the hole is drilled may be of very low thermal conductivity. Additional gradient measurements and thermal conductivity measurements will be required before the magnitude of heat flow can be calculated.

\section{HEAT SOURCE FOR NORTHERN WASATCH FRONT GEOTHERMAL SYSTEMS}

The thermal waters of the Wasatch Front are warmed by deep circulation of meteoric waters in 
a region of high heat flow. In the Basin and Range Province, temperature generally increases with depth at a rate of approximately $32^{\circ} \mathrm{C} / \mathrm{km}$. Under these conditions temperatures observed at the four thermal sites could be obtained by circulation of water to depths of approximately 2.5 to $3.0 \mathrm{~km}$. Water of $100^{\circ} \mathrm{C}$ could be obtained by circulation to a depth of approximately $4 \mathrm{~km}$.

The details of system recharge and fluid transport to depth for each geothermal site are not known but a generalized model can be used. Recharge to the systems is likely to occur in the Wasatch Range where snowmelt infiltrates the aquifers exposed in the range. By some presently unknown path, the water is transported downward through permeable rocks and fault zones to an intersection with a fault zone of high vertical permeability. The fault zone is a conduit through which the thermal water is transported rapidly to the surface, thus maintaining much of the heat transferred from the . rock. Depth of decent, rate of ascent, and degree of mixing with non-thermal water are the main factors influencing the temperature of the fluids observed.

Range front faults appear to be important conduits for thermal waters, and a number of springs are located near the oblique intersections of range front faults with other fractures. Gravity surveys at Utah Hot Springs, Crystal (Madsen) Hot Springs, and Udy Hot Springs may provide a significant contribution toward understanding the structural controls of Wasatch Front thermal springs. Detailed water sampling programs in these areas will help in determining recharge area.

\section{CONTINUING RESEARCH}

As this report of investigation was being prepared, additional research was in progress at a number of sites discussed above. Detailed gravity surveys are being conducted in the vicinity of Crystal (Madsen) and Udy Hot Springs. At Utah Hot Springs both a detail gravity survey and a detailed aeromagnetic survey will be conducted. Results of these surveys will be available in early 1980, however, reports containing thoughtful interpretations of the data may not be available until much later in 1980.

\section{REFERENCES}

BEUS, S. S., 1963, Geology of the Central Blue Spring Hills, Utah-Idaho: unpublished Ph. D. thesis, University of California, Los Angeles.

BJORKLUND, L. J., and L. J. McGreevy, 1974, Ground-water resources of the lower Bear River drainage basin, Box Elder County, Utah: Utah Department of Natural Resources Technical Publication no. 44.

BOLKE, E. L., and K. M. Waddell, 1972, Ground-water conditions in the East Shore area, Box Elder, Davis and Weber Counties, Utah, 1960-1969: State of Utah Department of Natural Resources Technical Publication no. 35. 
CLUFF, L. S., G. E. Brogan, and C. E. Glass, 1970, Wasatch Fault (northern portion): Earthquake Fault investigation and evaluation report to Utah Geological and Mineral Survey, by Woodward-Clyde and Associates.

CLUFF, L. S., C. E. Glass, and G. E. Brogan, 1974, Investigation and evaluation of the Northern Wasatch and Cache Valley Faults, Utah and Idaho: A guide to land-use planning with recommendation for seismic safety, report to U. S. Geological Survey, by Woodward-Lungren and Associates.

FELMLEE, J. K., and R. A. Cadigan, 1978, Determination of uranium in source rocks by using radium in Crystal Springs, Great Salt Lake area, Utah: U. S. Geological Survey Open-File Report 78-102.

FREMONT, J. C., 1845, Report of the exploring expeditions to the Rocky Mountains in the year 1842 and to Oregon and North California in the years 1843-44.

GILBERT, G. K., 1928, Studies of Basin and Range structure: U. S. Geological Survey Professional Paper 153.

GOODE, H. D., 1978, Thermal waters of Utah: Utah Geological and Mineral Survey Report of Investigation no. 129.

GUNNISON, J. W., 1853, in Stansbury, Howard, Explorations and survey of the valley of the Great Salt Lake of Utah, including a reconnaissance of a new route through the Rocky Mountains: 32nd Congress Special Session, S. Ex. Doc. 3.

HANSON, A. M., 1949, Geology of the southern Malad Range and vicinity in northern Utah: unpublished Ph. D. thesis, University of Wisconsin.

MILLIGAN, J. H., R. E. Marsell, and J. M. Bagley, 1966, Mineralized springs in Utah and their effect on manageable water supplies: Utah Water Research Laboratory, Utah State University Report WG23-6.

MUNDORFF, J. C., 1970, Thermal springs of Utah: Utah Geological and Mineral Survey Water Resources Bulletin no. 13.

MURPHY, P. J., and J. W. Gwynn, 1979, Geothermal investigations at Crystal Hot Springs, Salt Lake County, Utah: Utah Geological and Mineral Survey Report of Investigation no. 139.

O'CONNELL, M. F., and R. F. Raufmann, 1976, Radioactivity associated with geothermal waters in the Western United States, Basic data: U. S. Environmental Protection Agency, office of Radiation Programs Technical Note ORP/LV-75-8A, 25 p.

OLMSTED, F. H., 1977, Use of temperature surveys at a depth of 1 meter in geothermal exploration in Nevada (Geohydrology of geothermal systems): U. S. Geological Survey Professional Paper 1044-B.

PETERSON, D. L., 1974, Bouguer gravity map of part of the northern Lake Bonneville Basin, Utah and Idaho: U. S. Geological Survey Miscellaneous Field Studies Map MF-627.

STOKES, W. L., 1963, Geologic Map of northwestern Utah, scale, 1:250,000.

WILLIAMS, J. S., 1948, Geology of the Paleozoic rocks, Logan quadrangle, Utah: Geological Society of America Bulletin, vol. 59, p. 1121-1164. 

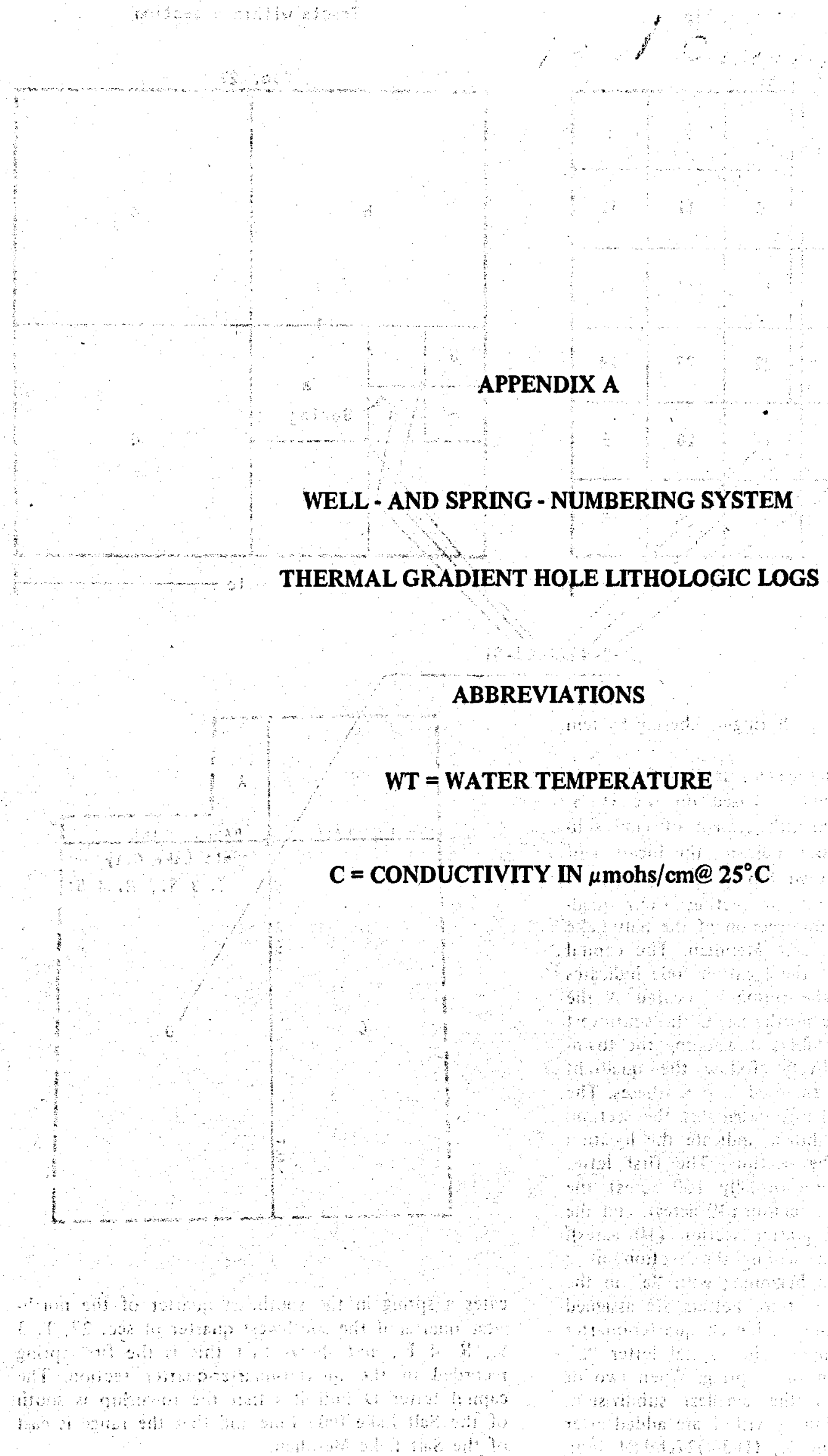
R. 4 E.

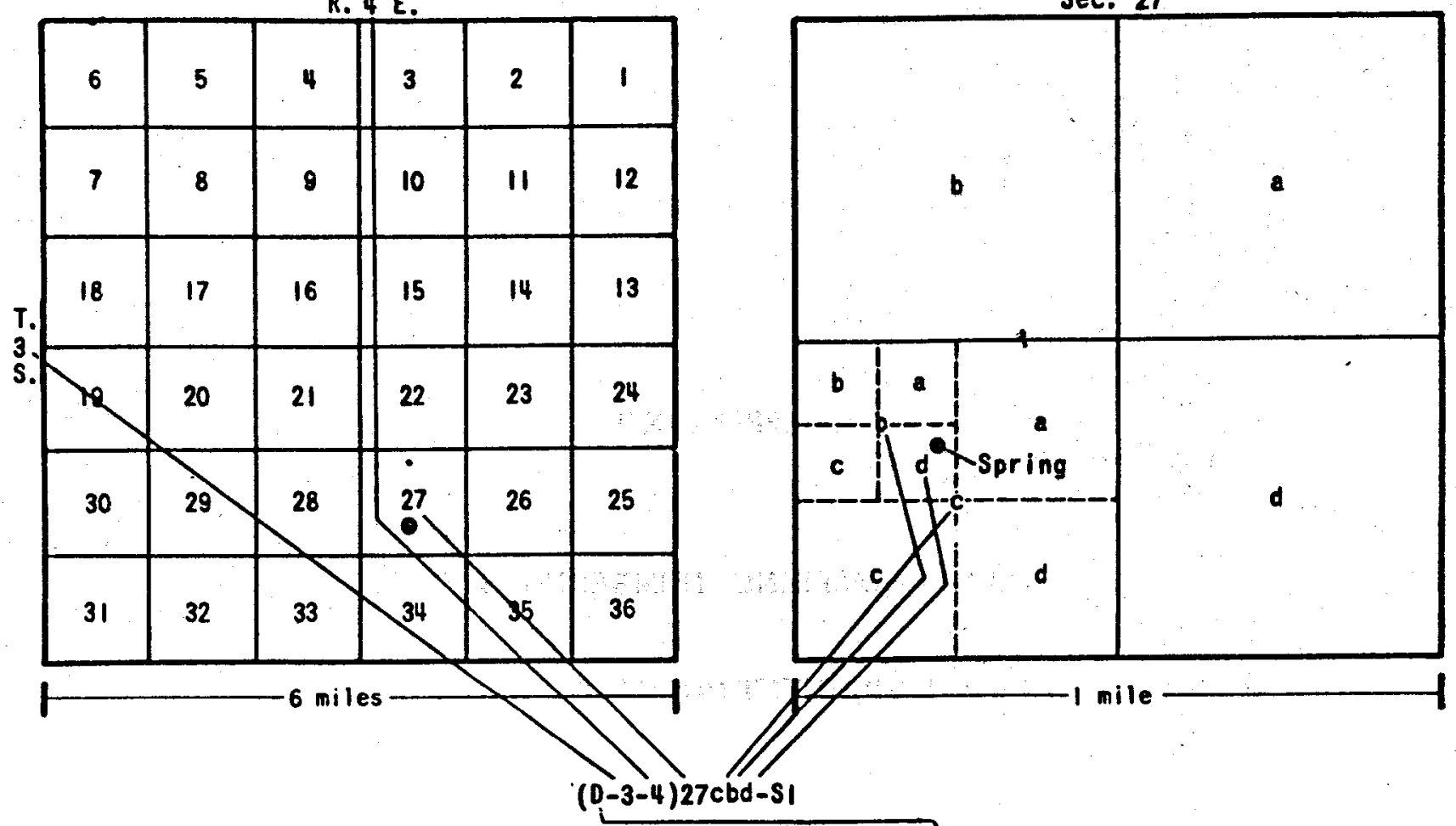

Spring-Ilumbering System

The spring-numbering system used in this report is shown in figure $I$ and is based on the U. $S$. Bureau of Land Management's system of land sub. division. The spring number indicates the location of the spring by quadrant, township, range, section, and position (if known) within the section. Four quadrants are formed by the intersection of the Salt Lake Base Line and the Salt Lake Meridian. The capital letter at the beginning of the location code indicates the quadrant in which the spring is located-A the northeast quadrant, $B$ the nurthwest, $C$ the southwest and $D$ the southeast. Numbers designating the township and range, respectively. follow the quadrant letter, and the three are enclosed in parentheses. The number after the parentheses designates the section; the lowercase letters, if shown, indicate the location of the spring within the section. The first letter denotes the quarter section (usually 160 acres), the second the quarter-quarter section (40 acres). and the third the quarter-quarter-quarter section (10 acres). The letters are assigned within the section in a counterclockwise direction beginning with "a" in the northeast quarter of the section. Letters are assigned within each quarter section and each quarter-quarter section in the same manner. The capital letter "S" completes the designation of a spring. When two or more springs are within the smallest subdivision, consecutive numbers beginning with 1 are added after the letter "S." For example, (D-3-4)27cbd-SI indi-

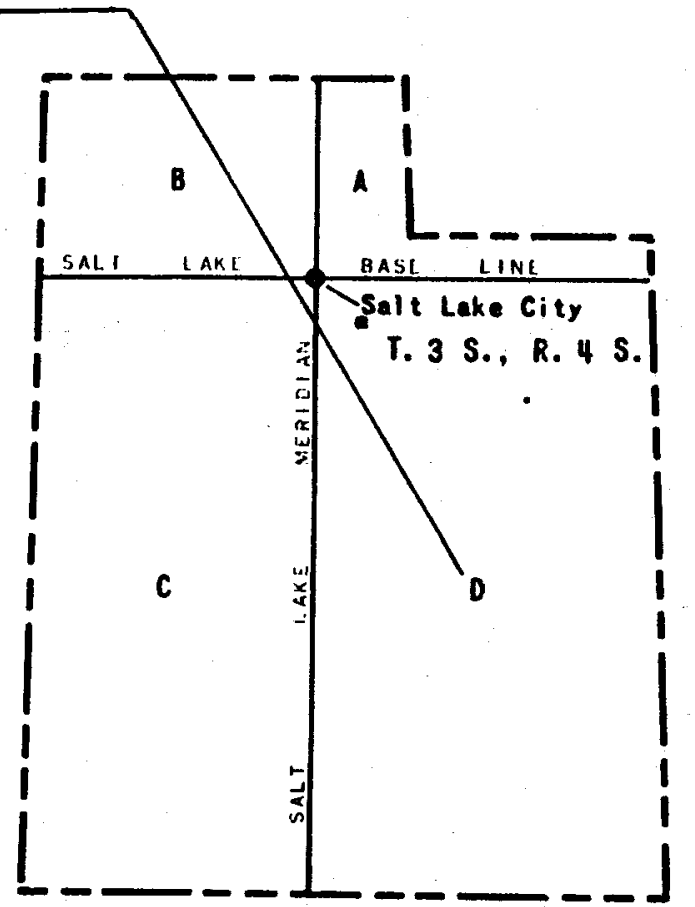

cates a spring in the southeast quarter of the northwest quarter of the southwest quarter of sec. 27, T. 3 S., R. 4 E., and shows that this is the first spring recorded in the quarter-quarter-quarter section. The capital letter $D$ indicates that the township is south of the Salt Lake Base Line and that the range is east of the Salt Lake Meridian. 


\section{Temperature Gradient Hole Log}

Hole $\mathrm{UT} / \mathrm{GH}-\mathrm{B}$ Location $(B-7-2) 14$ ddc

Surface Elevation 42801 Comp. Date_12 - 21 - 78 T. D. 1001

\section{whents Comments}

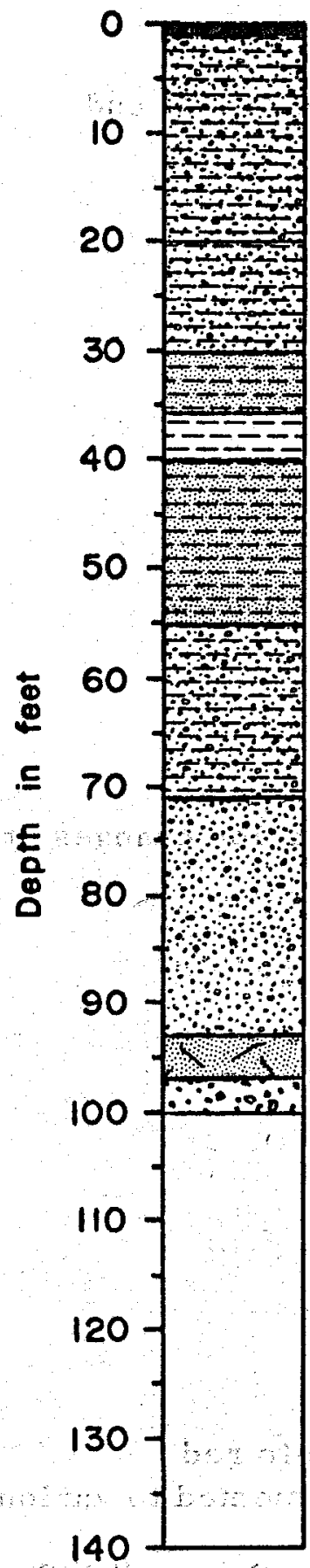

Road base

Brownish green clay with sand and fine gravel

Greenish clay with sand and minor fine gravel

Gray sandy clay

$\mathrm{WT}=30^{\circ} \mathrm{C}$, Quartzite boulder (?), no returns, drilling difficult

Gray sandy clay

Sand and gravel in varying proportions in gray clay (clay decreases with depth)

$\mathrm{WT}=44^{\circ} \mathrm{C}$, (volume increases with depth), C $=2.20$ $\times 10^{4}$, wood at $70^{\prime}$ Hole flows $11 \mathrm{gpm} @ 51.5^{\circ} \mathrm{C}$

Sand and gravel with minor clay. Gravel is well rounded quartzite, occasional lense of green clay

Quartzite boulder

Gravel and sand in yellow clay

Total depth

After reaching 100', hole began to flow $60 \mathrm{~g} \mathrm{pm}$ at $59^{\circ} \mathrm{C}, \mathrm{C}=4.05 \times 10^{4}$

Spring $\quad \mathrm{WT}=60^{\circ} \mathrm{C}$

$\mathrm{C}=3.01 \times 10^{4}$ 


\section{Temperature Gradient Hole Log}

Hole $\mathrm{C}(\mathrm{M}) / \mathrm{GH}-\mathrm{A}$

Location $(B-11-2) 29$ dda

Surface Elevation $4300^{\prime}$ Comp. Date $3-13-79$ T. D. 2801

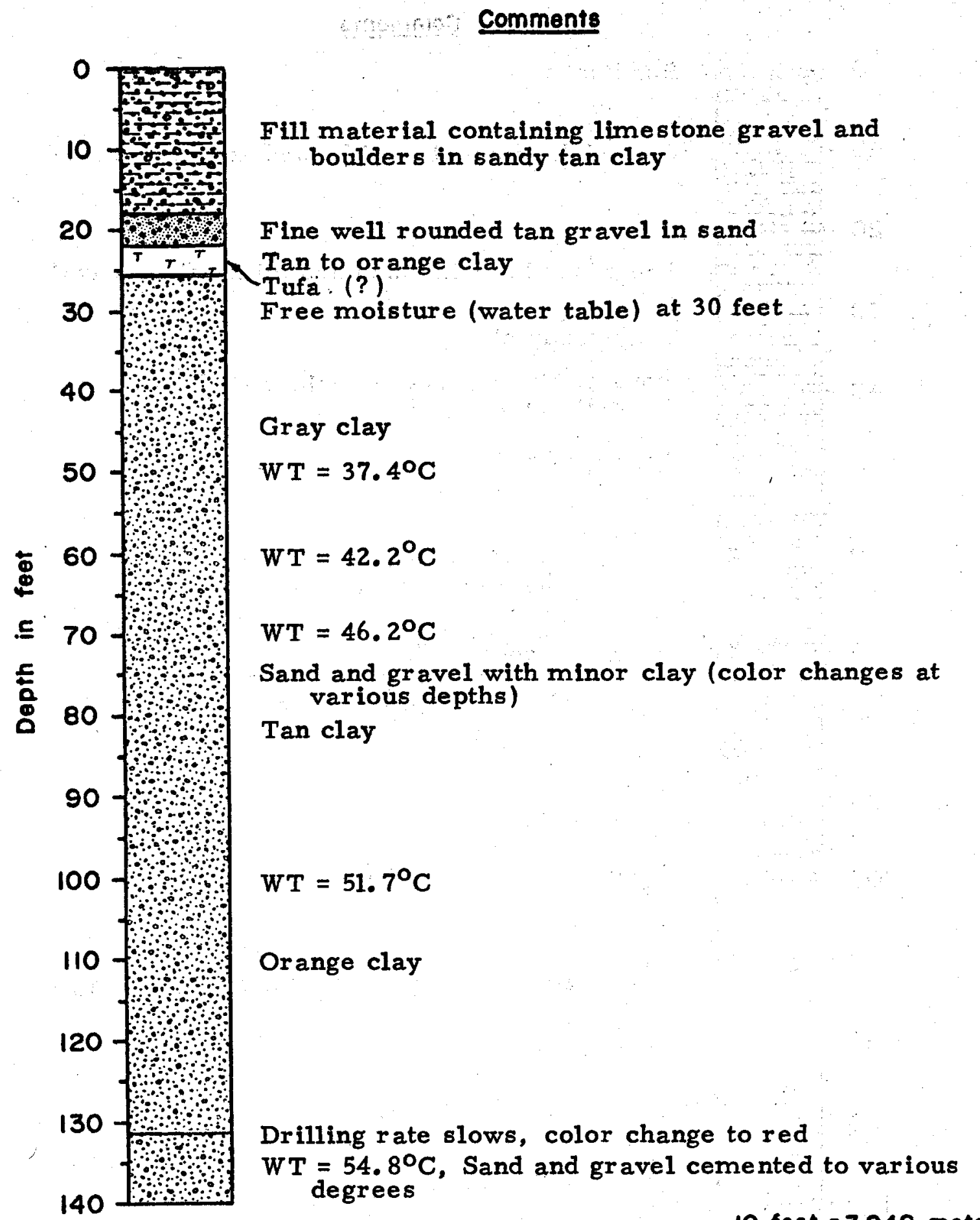




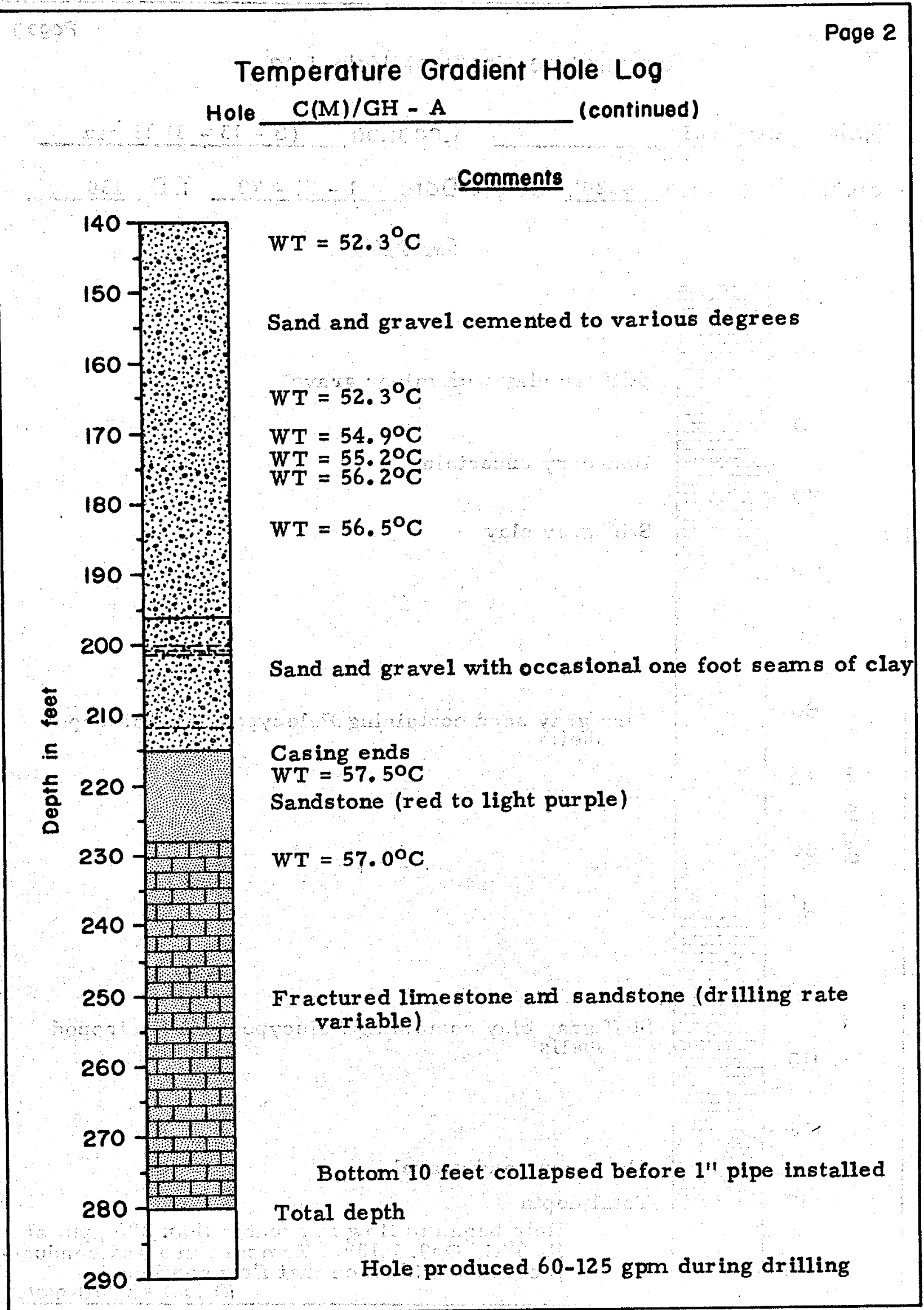


Temperature Gradient Hole Log

Hole UDY/GH - A Location (B-13-3)23 baa

Surface Elevation $4320^{\prime}$ Comp. Date $1-21-79$ T. D. 130

\section{Comments}

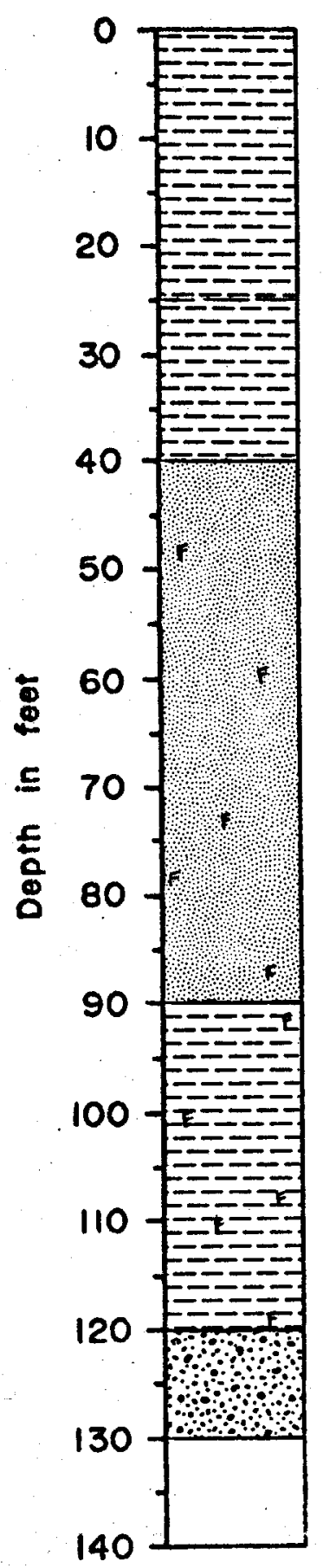

Stiff tan clay with minor gravel

Boundary uncertain

Stiff gray clay

Fine gray sand containing Pelecypod and Gastropod shells

Stiff gray clay containing Pelecypod and Gastropod shells

Clean sand and gravel

Total depth

Hole began to flow at greater than $200 \mathrm{gpm}$ at $18.6^{\circ} \mathrm{C}, \mathrm{C}=9.5 \times 10^{2}$. Temperature and conductincreased with time that flow continued. 
Temperature Gradient Hole Log

Hole UDY/GH - B

Location

$(B-13-3) 23 \mathrm{bbd}$

Surface Elevation $4400^{\prime}$ Comp. Date $2-22-79$ T. D. $270^{\prime}$

\section{Comments}

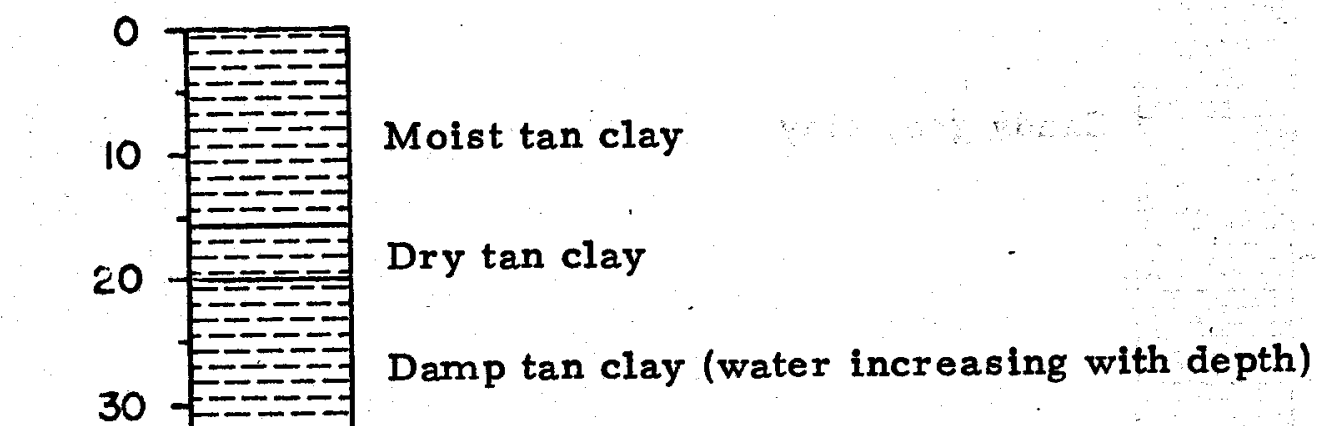

Boundary uncertain

Sandy gray clay

$\mathrm{WT}=23.3^{\circ} \mathrm{C}$, Fine sand with minor clay, zone is

Log encountered (wood in returns)

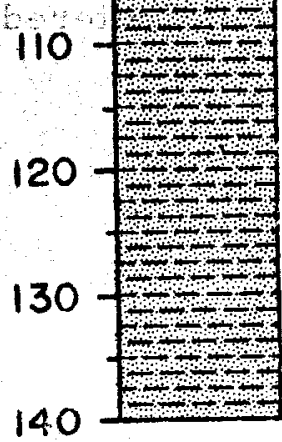

Sandy gray clay 
Temperature Gradient Hole Log Hole UDY/GH - B (continued)

\section{Page 2}

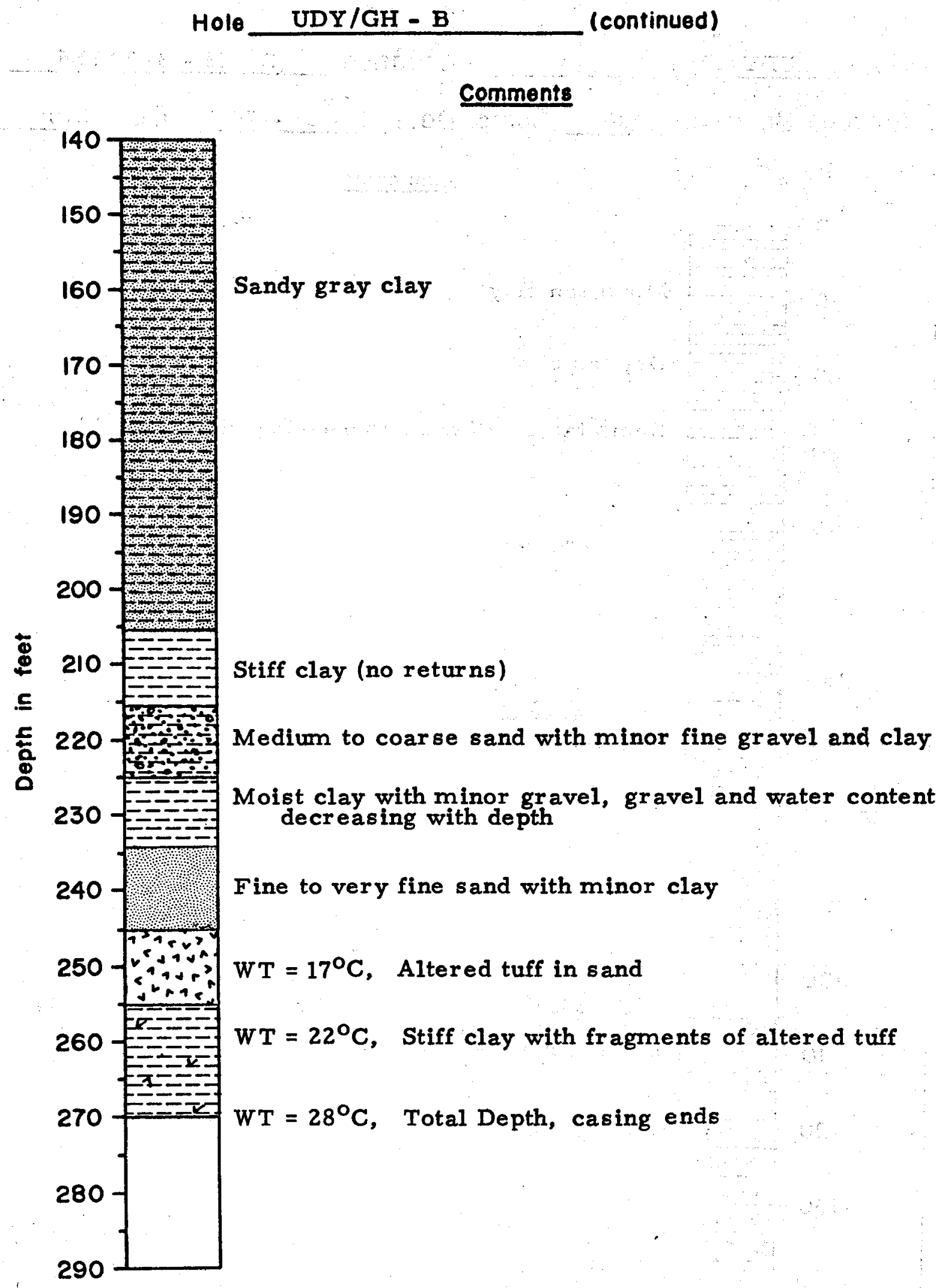




\section{Temperature Gradient Hole Log}

Hole GSLM /GH - A Location (B-6-3) $6 \mathrm{cab}$

Surface Elevation 42201 Comp. Date $5-10-79$ T. D. $280^{\prime}$

\section{Comments}

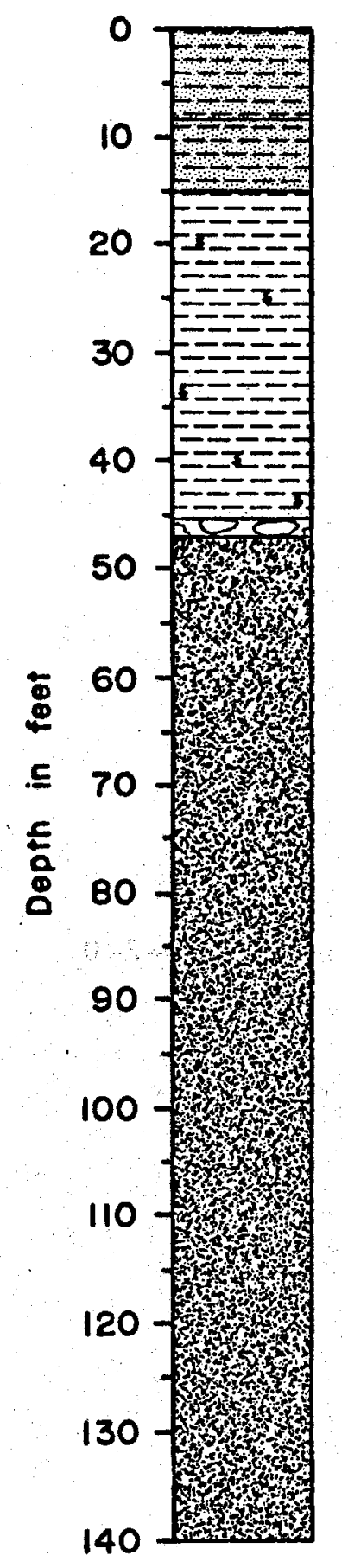

Tan sandy clay

Saturated sandy black clay

Weathered shale fragments in clay

Boulders

$\mathrm{WT}=16.5^{\circ} \mathrm{C}, \mathrm{C}=9.75 \times 10^{3}$

Tillite bedrock

Portions of hole cave 80-100' particularly difficult to deep open. Drelling required $800-1000 \mathrm{lbs}$ down pressure to maintain rates between 40 and 90 minutes per 10 feet.

$\mathrm{WT}=17.2^{\circ} \mathrm{C}$ 
Temperature Gradient Hole Log Hole GSLM/GH - A (continued)

\section{Comments}

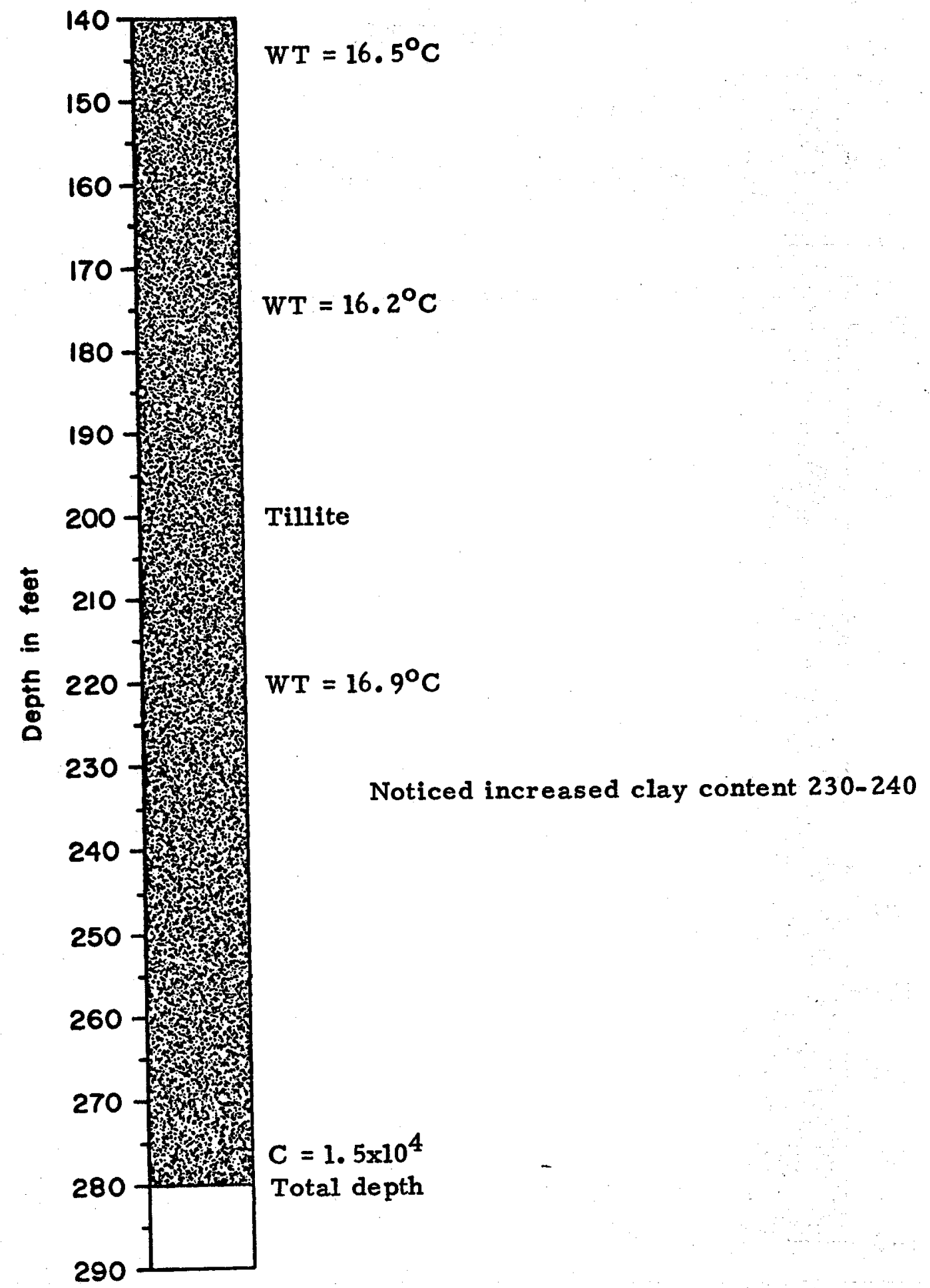

